Review

\title{
Meat provenance: Authentication of geographical origin and dietary background of meat
}

\author{
Frank J. Monahan ${ }^{\mathrm{a}, *}$, Olaf Schmidt ${ }^{\mathrm{a}}$, Aidan P. Moloney ${ }^{\mathrm{b}}$ \\ ${ }^{\text {a } U n i v e r s i t y ~ C o l l e g e ~ D u b l i n, ~ S c h o o l ~ o f ~ A g r i c u l t u r e ~ a n d ~ F o o d ~ S c i e n c e, ~ D u b l i n ~ 4, ~ I r e l a n d ~}$ \\ b Teagasc, Animal \& Grassland Research and Innovation Centre, Grange, Co. Meath, Ireland
}

\section{A R T I C L E I N F O}

\section{Keywords:}

Authenticity

Fraud

Hair

Isotopes

Muscle

Validation

\begin{abstract}
A B S T R A C T
The authenticity of meat is now an important consideration in the multi-step food chain from production of animals on farm to consumer consumption of the final meat product. A range of techniques, involving analysis of elemental and molecular constituents of meat, fingerprint profiling and multivariate statistical analysis exists and these techniques are evolving in the quest to provide robust methods of establishing the dietary background of animals and the geographical origin of the meat derived from them. The potential application to meat authentication of techniques such as stable isotope ratio analysis applied to different animal tissues, measurement in meat of compounds directly derived from the diet of animals, such as fatty acids and fat soluble vitamins, and spectroscopy is explored. Challenges pertaining to the interpretation of data, as they relate to assignment of dietary background or geographical origin, are discussed.
\end{abstract}

\section{Introduction}

Provenance, according to the Oxford dictionary, is defined as "the place of origin or earliest known history of something", "the beginning of something's existence" or "a record of ownership ... used as a guide to authenticity or quality". In the context of food, and meat particularly, provenance therefore encompasses geographical origin, farm production system, and a record of the meat's journey from the farm to the consumer's table. Traceability, defined as "the ability to follow the movement of a food through specified stages of production, processing and distribution" (WHO/FAO, 2007), and traceability systems may be understood as seeking to protect the latter record of a food's journey from farm to consumer. Therefore, food authentication, "the process by which a food is verified as complying with its label description" (Dennis, 1998), is critical to establishing the provenance of food and validating the traceability systems that may be in place to underpin its provenance.

Food provenance is an important consideration for food producers and consumers alike. For consumers, foods of animal origin, such as meat products, may have a particular value associated with the geographical origin or production system from which they derive, e.g. "Protected Designation of Origin (PDO)", "Protected Geographical Indication (PGI)", "Traditional Speciality Guaranteed (TSG)", "organic", "free range" or "grass-fed" (Camin et al., 2017; Daley, Abbott, Doyle, Nader, \& Larson, 2010; McCluskey, Wahl, Li, \& Wandschneider,
2005). Consumers are willing to pay a premium for these products and in the future they may pay more for meat generally as sustainability issues come to the fore (Henchion, McCarthy, Resconi, \& Troy, 2014). Food producers increasingly seek to maximise the market potential of their products based on, for example, the traditional nature or sustainability of the production system or the nutritional profile of their products. A consequence of this desire to "add-value" is concern among food producers and consumers about food fraud, whereby counterfeit substitutes replace authentic foods (Primrose, Woolfe, \& Rollinson, 2010).

In the case of animal-derived foods generally, and meat specifically, not only is geographical origin important but so also is the verification of the dietary background of animals because diet can be a distinct feature of certain production systems, e.g. "organic" or "grass-fed" and it can have profound effects on the composition and quality (nutritional and sensory) and the sustainability of production of animal derived food products (Woods \& Fearon, 2009). Thus, for example, verification that "grass-fed beef" is in fact from grass-fed animals or that "corn fed" chicken is in fact corn-fed is required (Osorio, Moloney, Schmidt, \& Monahan, 2011a; Rhodes et al., 2010). In Ireland, beef for the U.S. market must be from animals with a "More than $80 \%$ Grass Diet" (Bord Bia, 2017). The challenge of authentication is even greater when comminuted or re-formed meat products are considered and issues such as speciation, proportion of ingredients used and addition of undeclared ingredients become important (Montowska \& Pospiech, 2012). There

\footnotetext{
* Corresponding author.

E-mail addresses: frank.monahan@ucd.ie (F.J. Monahan), olaf.schmidt@ucd.ie (O. Schmidt), aidan.moloney@teagasc.ie (A.P. Moloney).
} 
are already several volumes and review articles on the subject of food authentication (Lees, 2003; Luykx \& Van Ruth, 2008; Primrose et al., 2010; Sun, 2008) and on meat authentication specifically (Arvanitoyannis, 2016; Ballin, 2010; Montowska \& Pospiech, 2012; Sentandreu \& Sentandreu, 2014) available. The current article will deal with meat provenance authentication in the context of fresh (unprocessed) meats mainly, but many of the methods discussed and the examples given have applicability for processed meats too. A particular focus of the article will be on developments relating to determination of dietary background and geographical origin of meats.

\subsection{Methods used in meat provenance authentication}

A wide range of analytical measurements has found application in meat authentication (Arvanitoyannis, 2016; Ballin, 2010; Danezis, Tsagkaris, Camin, Brusic, \& Georgiou, 2016; Montowska \& Pospiech, 2012; Nader, Brendel, \& Schubbert, 2016). In terms of the geographical origin and dietary background of meat, methods involving the measurement of quantifiable components at both an elemental and molecular level have been applied, including: stable isotopes (Heaton, Kelly, Hoogewerff, \& Woolfe, 2008); trace elements (Franke, Hadorn, Bosset, Gremaud, \& Kreuzer, 2008; Franke et al., 2007); fatty acids (Alfaia et al., 2009); volatile organic compounds, such as terpenes and phenolics (Priolo et al., 2004); carotenoids (Prache, Priolo, \& Grolier, 2003a) and vitamin E (Röhrle, Moloney, Black, et al., 2011). It is well established that these constituents of meat are directly influenced by the diet consumed by animals and therefore they can provide information about the dietary background of animals. In addition, some of the above "markers" can also be extremely useful for assignment of geographical origin if, for example, specific feedstuffs are associated with a particular geographical region (Schmidt et al., 2005) or are influenced by regional climatic conditions or underlying geology (Сapo, Stewart, \& Chadwick, 1998). As well as measurement of elemental or molecular markers, a "fingerprint" approach can also be taken whereby spectroscopic techniques are used to determine differences in the optical properties of foods derived from different production systems (Downey, 2016; Prache, 2009).

Furthermore, DNA-based methods are used widely in meat authentication by providing a direct link between meat products and the animals from which they derive (Nader et al., 2016). While they do not provide information about the dietary background or farm of origin or production system, they play an important role in traceability systems, linking meat or meat products back to an individual animal or breed and form the basis of several commercial traceability systems, e.g. DNA TraceBACK (Identigen, 2018). DNA-based methods have also been widely used in speciation (Amaral, Meira, Oliveira, \& Mafra, 2016) and in meat fraud detection, e.g. in the horsemeat scandal in the European Union in 2013 (FSA, 2013). In addition, molecular approaches may be used to study the impact of production systems on gene expression (Hocquette, Cassar-Malek, Bernard-Capel, \& Picard, 2009; Sweeney et al., 2016).

The analytical techniques applicable to food authentication are also well documented: they include chromatography (GC, HPLC), isotope ratio mass spectrometry (IRMS), inductively coupled plasma mass spectrometry (ICP-MS), spectroscopy (IR, NMR, UV, fluorescence, Raman), molecular (DNA and PCR-based) techniques and enzymatic techniques (Downey, 2016; Lees, 2003; Luykx \& Van Ruth, 2008; Primrose et al., 2010; Sun, 2008). In the following sections some of the more promising approaches to authentication of the dietary background and geographical origin of meat are discussed.

\section{Stable isotope ratio analysis}

Stable isotope ratio analysis (SIRA) involves the measurement of ratios of stable isotopes of bioelements, frequently including carbon $\left({ }^{13} \mathrm{C} /{ }^{12} \mathrm{C}\right)$, nitrogen $\left({ }^{15} \mathrm{~N} /{ }^{14} \mathrm{~N}\right)$, hydrogen $\left({ }^{2} \mathrm{H} /{ }^{1} \mathrm{H}\right)$, oxygen $\left({ }^{18} \mathrm{O} /{ }^{16} \mathrm{O}\right)$ and sulphur $\left({ }^{34} \mathrm{~S} /{ }^{32} \mathrm{~S}\right)$. Isotope Ratio Mass Spectrometry is typically used for SIRA and the data obtained are reported as delta $(\delta)$ values, in per mil (\%) units, with $\delta^{13} \mathrm{C}, \delta^{15} \mathrm{~N}, \delta^{2} \mathrm{H}, \delta^{18} \mathrm{O}$ and $\delta^{34} \mathrm{~S}$ notation for ratios of ${ }^{13} \mathrm{C} /{ }^{12} \mathrm{C},{ }^{15} \mathrm{~N} /{ }^{14} \mathrm{~N},{ }^{2} \mathrm{H} /{ }^{1} \mathrm{H},{ }^{18} \mathrm{O} /{ }^{16} \mathrm{O}$ and ${ }^{34} \mathrm{~S} /{ }^{32} \mathrm{~S}$, respectively (Kelly, Heaton, \& Hoogewerff, 2005). A strong scientific framework exists for isotope ratio measurements in forensic applications (Cerling et al., 2016); meat provenance studies can build on these analytical, biochemical and geological foundations.

It is well established that the stable isotope composition of bioelements in animal tissue is influenced by the composition of the diet consumed by the animal (DeNiro \& Epstein, 1978); therefore, stable isotope signatures obtained from an animal's tissues can provide useful information about the diet consumed by that animal. Thus, $\mathrm{C}$ and $\mathrm{N}$ isotopic compositions of animal products can be related to production system, e.g. $\mathrm{C}_{3}$ vs $\mathrm{C}_{4}$ (photosynthetic pathway) crops, pasture vs cerealbased or organic vs conventional systems (Osorio et al., 2011a; Schmidt et al., 2005). In addition, while not direct indicators of geographical origin, ${ }^{13} \mathrm{C} /{ }^{12} \mathrm{C}$ and ${ }^{15} \mathrm{~N} /{ }^{14} \mathrm{~N}$ ratios can be useful in indirectly determining geographical provenance if a particular feedstuff is typically fed in a particular region or if analysed in combination with other stable isotopes such as hydrogen and oxygen isotopes (Nakashita et al., 2008). The latter two elements are especially useful for geographical origin assignment of food linked to regional climatic conditions (Kelly et al., 2005) because they are strongly latitude dependent and they are also affected by altitude, distance from the sea, total precipitation and seasonality (Rozanski, Araguas-Araguas, \& Gonfiantini, 1992). Sulphur isotopic compositions are mainly affected by the geology of the area where animal feed is grown (sedimentary or igneous) (Rossmann et al., 2000) as well as the proximity to the sea, climatic conditions and fertilization practices (Krouse \& Grinenko, 1991).

In meat, SIRA has been shown to be particularly useful in the assignment of dietary background (Bahar et al., 2008; González-Martin, González-Pérez, Mendez, Marqués-Macias, \& Poveda, 1999; Piasentier, Valusso, Camin, \& Versini, 2003) and geographical origin (Boner \& Förstel, 2004; Camin et al., 2007; Chesson, Podlesak, Thompson, Cerling, \& Ehleringer, 2008; Guo, Wei, Pan, \& Li, 2010; Nakashita et al., 2008; Schmidt et al., 2005). The technique has been applied across all species: beef (Bong et al., 2010; Guo et al., 2010; Heaton et al., 2008; Nakashita et al., 2008; Renou et al., 2004); pork (González-Martin et al., 1999); lamb (Perini, Camin, Bontempo, Rossmann, \& Piasentier, 2009); poultry (Franke, Hadorn, et al., 2008); fish (Li, Boyd, \& Sun, 2016; Vinci, Preti, Tieri, \& Vieri, 2013) and even invertebrate species (Gamboa-Delgado et al., 2014).

\subsection{Stable isotopes and the dietary background of meat}

The underlying reason for large differences in $\delta^{13} \mathrm{C}$ values in meat from different production systems is frequently the different proportions of $\mathrm{C}_{3}$ and $\mathrm{C}_{4}$ plant species in the diets consumed by animals (Smith \& Epstein, 1971). For example, beef from cattle consuming a predominantly $C_{3}$ (temperate grass silage) diet $\left(\delta^{13} \mathrm{C}=-29.6 \%\right.$ ) was clearly distinguishable from that of animals consuming a predominantly $\mathrm{C}_{4}$ (maize silage) diet $\left(\delta^{13} \mathrm{C}=-11.8 \%\right.$ ) (Fig. 1) (Bahar et al., 2005). In the same study, the $\delta^{15} \mathrm{~N}$ values of the diets $(8.1 \%$ and $3.3 \%$ in the grass and maize silages, respectively) were also clearly reflected in those of the beef. Even in beef from animals consuming diets with a lower isotopic spacing, for example barley vs grass-based diets (both $\mathrm{C}_{3}$ plant species) in which a dietary spacing of 2 to $3 \%$ in $\delta^{13} \mathrm{C}$ values exists, it was possible to discriminate between beef from animals raised on the different diets (Osorio et al., 2011a) (Fig. 2). In Switzerland, Richter, Spangenberg, Willems, Kreuzer, and Leiber (2012) used bulk and fatty acid compound specific C isotope analysis to distinguish between lowland and mountain pasture lambs, with a $\delta^{13} \mathrm{C}$ difference in the vegetation of $2.5 \%$ o between the two sites. In British chicken, Rhodes et al. (2010) demonstrated the usefulness of SIRA in distinguishing between chicken from birds fed varying levels of maize 


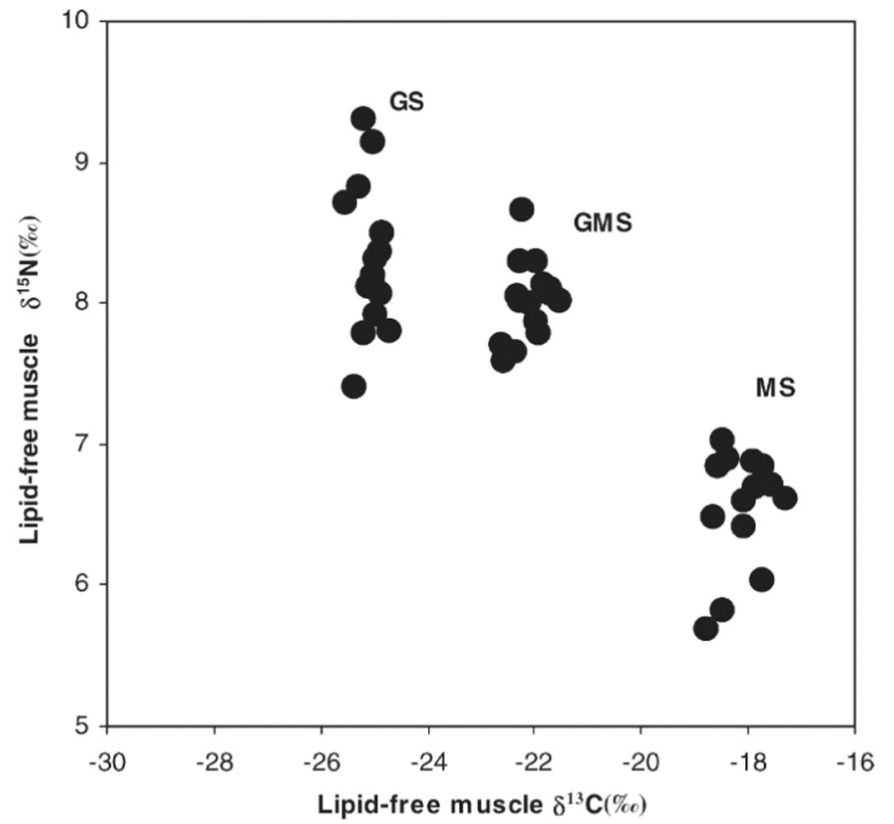

Fig. 1. $\delta^{15} \mathrm{~N} v s \delta^{13} \mathrm{C}$ values of bovine muscle of animals fed ad libitum as follows: grass silage (GS), maize silage (MS) or equal proportions [dry matter basis] of grass silage and maize silage (GMS) (from Bahar et al. (2005).

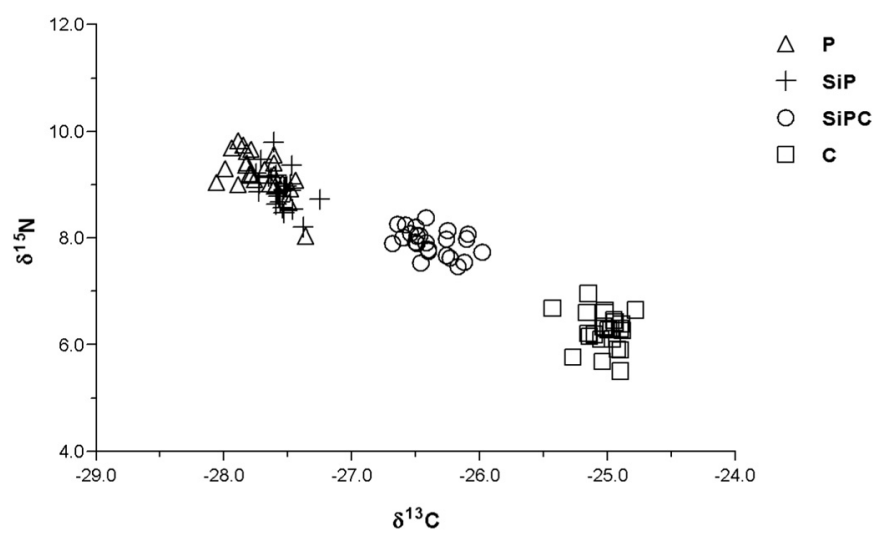

Fig. 2. $\delta^{15} \mathrm{~N} v s \delta^{13} \mathrm{C}$ values of bovine muscle of animals fed as follows: grass at pasture for 12 months (P); grass silage for 6 months followed by grass at pasture for 6 months (SiP); grass silage for 6 months followed by grass at pasture with a barley-based concentrate ( 0.5 of total dry matter) for 6 months (SiPC); or a barley-based concentrate for 12 months (C). The $\delta^{13} \mathrm{C}$ values of feedstuffs were $-30.9,-29.2$, and $-27.9 \%$ for the pasture, silage and concentrate, respectively. The $\delta^{15} \mathrm{~N}$ values of feedstuffs were $6.4,5.0$ and $3.4 \%$ for the pasture, silage and concentrate, respectively (from Osorio et al. (2011a)).

(the diet of "corn-fed" chickens must contain at least 50\% maize). There was a clear relationship between the dietary maize level and the $\delta^{13} \mathrm{C}$ values in muscle and lipid of chicken (Fig. 3). However, in a Brazilian study, Coletta et al. (2012) recommend caution in using carbon and nitrogen stable isotope composition to certify free-range chickens since certain combinations of ingredients in a diet could give similar compositions in barn-fed and free-range chickens. Thus, while free range chickens could have a high $\delta^{13} \mathrm{C}$ due consumption of $\mathrm{C}_{4}$ grasses, barnfed chickens could have a similar value due to consumption of maize.

\subsection{Stable isotopes and the geographical origin of meat}

Differences in $\mathrm{C}$ and $\mathrm{N}$ isotopic signatures of meat from different geographical regions may, similarly, be attributed to differences in the isotopic signature of the dominant feedstuffs fed in the region. Thus, for

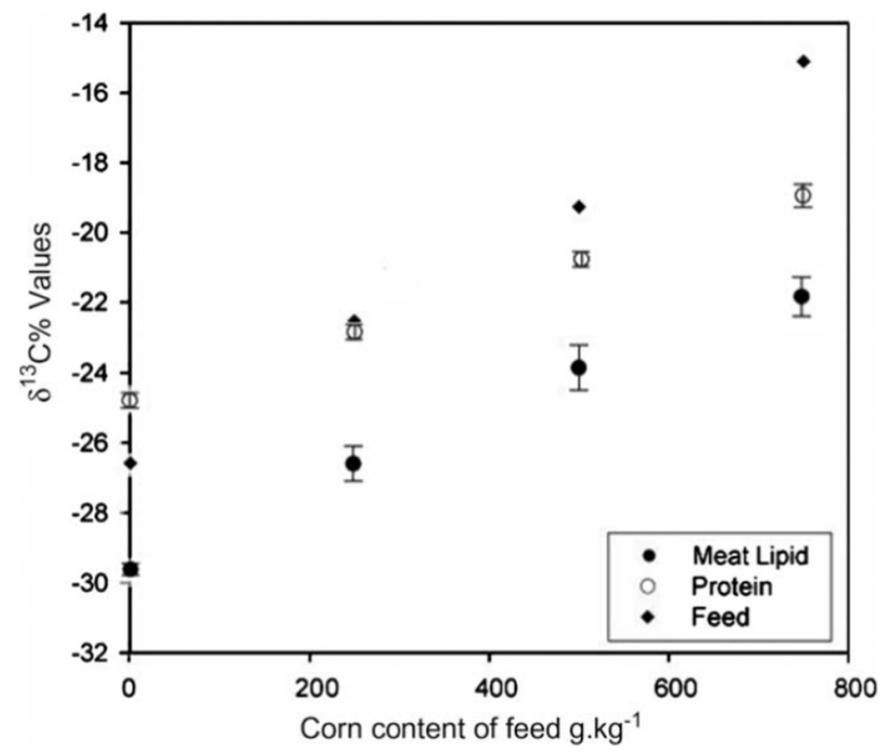

Fig. 3. $\delta^{13} \mathrm{C}$ values of defatted chicken muscle (protein) and muscle lipid of Hubbard chickens fed increasing levels of maize (corn) (from Rhodes et al. (2010)).

example Piasentier et al. (2003) reported $\delta^{15} \mathrm{~N}$ and $\delta^{13} \mathrm{C}$ values in lamb samples from six European countries, encompassing three broad production systems, and canonical discriminant analysis allowed a correct assignment, on the basis of production system, of $91.7 \%$ of samples. Similarly, Erasmus, Muller, Butler, and Hoffman (2018) showed that lamb from different regions in South Africa can be distinguished using $\delta^{15} \mathrm{~N}$ and $\delta^{13} \mathrm{C}$ because regions differ in aridity as well as amounts of $\mathrm{C}_{3}$ fodder plants (lucerne and Karoo bushes) versus savanna-type $\mathrm{C}_{4}$ grasses. In an international survey, Martinelli et al. (2011) used C isotope analysis to illustrate the so called "glocal" nature of the Big $\mathrm{Mac}^{\circledR}$ a global food with local signatures arising from the feedstuffs consumed by the animals (Fig. 4). Even within the U.S. different feedstuffs most likely contributed to a range of $11.8 \%$ o $\left(-25.5\right.$ to $-13.7 \%$ ) in $\delta^{13} \mathrm{C}$ values of beef burgers sampled in a number of fast food chains across the U.S. (Jahren \& Kraft, 2008). For chicken, the range in $\delta^{13} \mathrm{C}$ values was lower (range $2.7 \%$ o ( -19.3 to $-16.6 \%$ )) probably reflecting greater uniformity in maize consumption in chickens supplied across all outlets.

In the context of inter-regional and continental trade in animal feedstuffs, a potential shortcoming of using $\mathrm{C}$ and $\mathrm{N}$ for geographical assignment of meat is that, since both are largely influenced by dietary input, meat from animals raised at different geographical locations and consuming diets isotopically similar in $\mathrm{C}$ and $\mathrm{N}$, may not be distinguishable. In this scenario, SIRA of isotopes of $\mathrm{H}$ and $\mathrm{O}$ is particularly useful because ${ }^{2} \mathrm{H} /{ }^{1} \mathrm{H}$ and ${ }^{18} \mathrm{O} /{ }^{16} \mathrm{O}$ ratios reflect regional climatic conditions, being influenced by altitude and latitude for example, and are consumed by animals in the form of water (Kelly et al., 2005). Similarly, $\mathrm{S}$ deposited as sea spray, and therefore influenced by proximity to the sea, is a useful geographical indicator (Zazzo, Monahan, Moloney, Green, \& Schmidt, 2011). Camin et al. (2007) used multielement stable isotope analysis ( $, \mathrm{N}, \mathrm{H}, \mathrm{S}$ ) to discriminate between lamb sourced from different parts of Europe and with linear discriminant analysis obtained a correct classification of $78.7 \%(77.6 \%$ on cross-validation) (Fig. 5). In beef, Osorio, Moloney, Schmidt, and Monahan (2011b) investigated the feasibility of discriminating Irish grass-fed beef from beef obtained from six other European countries, the U.S. and Brazil. Using canonical discriminant analysis applied to stable isotope data $\left(\delta^{2} \mathrm{H}, \delta^{13} \mathrm{C}, \delta^{15} \mathrm{~N}, \delta^{34} \mathrm{~S}\right), 85.0 \%$ of the 140 beef samples were correctly assigned to country of origin and $82.9 \%$ with leave-one-out cross-validation (Fig. 6). Interestingly, from a labelling perspective, all Irish grass-fed beef samples used in the study were 


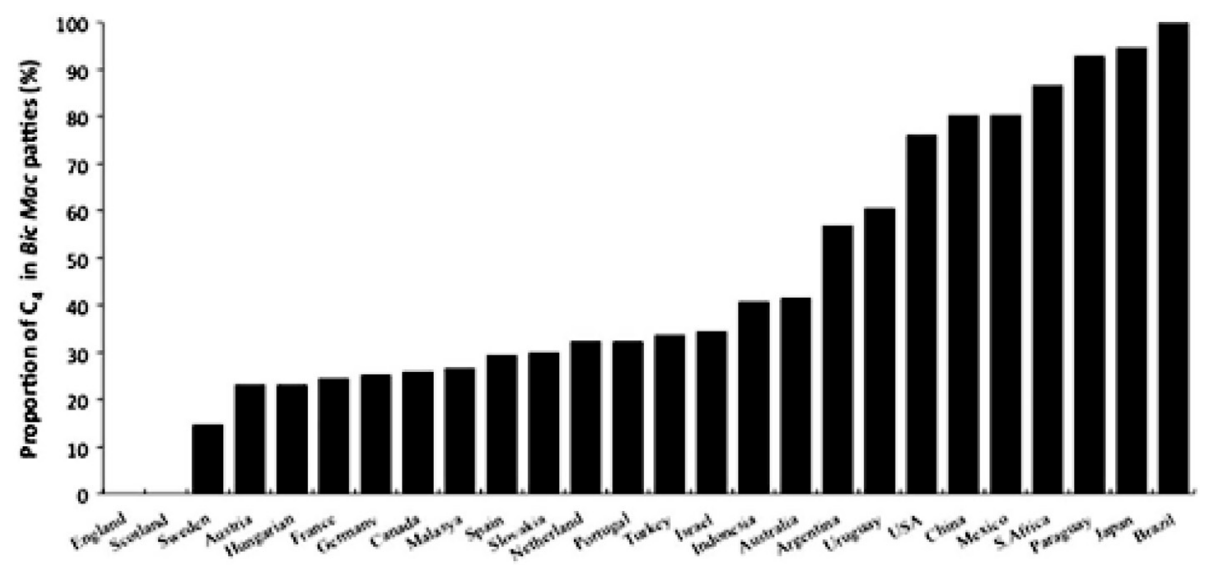

Fig. 4. Relative proportion of $\mathrm{C}_{4}$ plants in patties of Big Macs ${ }^{\circledast}$ sampled in different countries (from Martinelli et al. (2011)).

correctly classified.

In response to concerns about the authenticity of chicken labelled "Irish", we investigated the potential to discriminate between Irish and non-Irish chicken samples using $\mathrm{H}, \mathrm{C}, \mathrm{N}, \mathrm{O}$ and $\mathrm{S}$ analysis. Mean $\delta^{2} \mathrm{H}$, $\delta^{13} \mathrm{C}, \delta^{18} \mathrm{O}$ and $\delta^{34} \mathrm{~S}$ values of the Irish and non-Irish samples were significantly different $(\mathrm{p}<.001, \mathrm{p}<.001, \mathrm{p}<.001$ and $\mathrm{p}<.005$, respectively) while mean $\delta^{15} \mathrm{~N}$ values were similar (Table 1 ). It is noteworthy that significant differences were found in the isotopic signatures of the elements known to be good indicators of geographical origin, namely $\mathrm{H}, \mathrm{O}$ and $\mathrm{S}$. In particular, the large $\delta^{2} \mathrm{H}$ difference agrees with the main conclusion of the global survey of Rees et al. (2016) that $\delta^{2} \mathrm{H}$ is the best discriminator for poultry because of differences in drinking water. The difference in $\delta^{13} \mathrm{C}$ values may reflect a higher consumption of $\mathrm{C}_{3}$ relative to $\mathrm{C}_{4}$ plant material in chickens raised in Ireland. Principal component analysis (PCA) carried out on the 106 chicken sample dataset (56 Irish, 50 non-Irish) revealed clear separation of the two origins (i.e. "Irish" vs "Non-Irish") using all five stable isotope ratios (Fig. 7). The results of the linear discriminant analysis of the data are presented in Table 2. Overall, $96.2 \%$ of the original grouped cases (Irish and non-Irish chicken) were classified correctly while $95.3 \%$ of the cross-validated grouped cases were correctly identified. This is a promising outcome if one considers that authenticating chicken meat is very challenging because the production of these birds usually does not expose them to regionally identifiable environmental factors (climate, distance to sea, geology) or feeds such as pasture

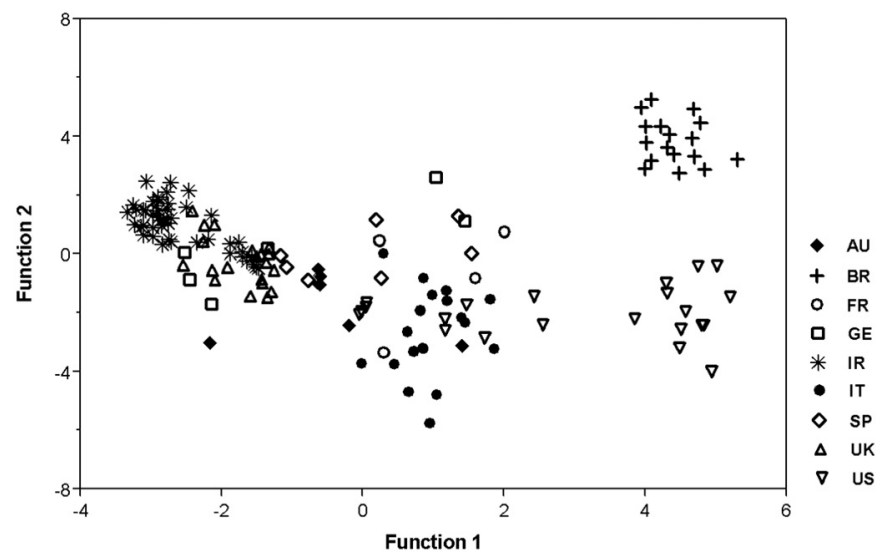

Fig. 6. Plot showing the first two discriminant functions obtained following canonical discriminant analysis of stable isotopic signatures (C, N, H and S) measured in bovine muscle from beef samples of different countries of origin. AU, Austria; BR, Brazil; FR, France; GE, Germany; IR, Ireland; IT, Italy; SP, Spain; UK, United Kingdom; US, United States (from Osorio et al. (2011b)).

plants that incorporate local isotope signals.

As strontium is a heavy element, its isotope ratio $\left({ }^{87} \mathrm{Sr} /{ }^{86} \mathrm{Sr}\right)$ in foods is influenced by underlying geology and its measurement has been used in regional assignment of plant products and mineral waters

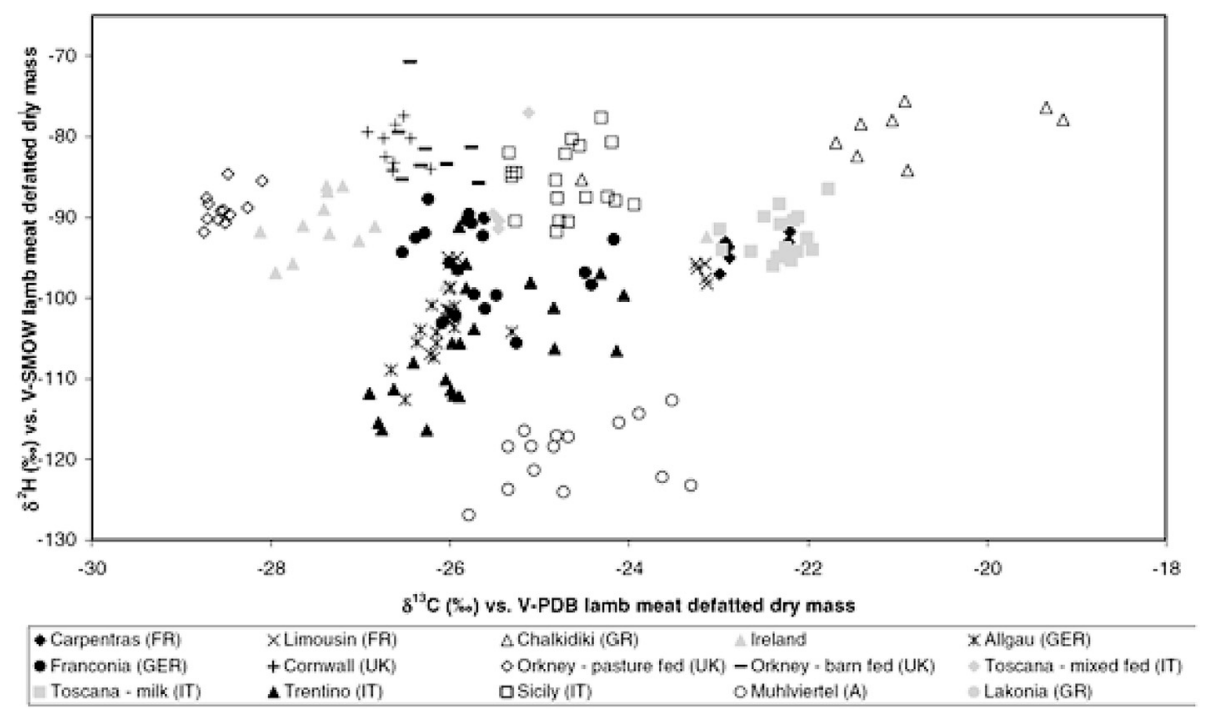

Fig. 5. Carbon and hydrogen isotopic ratios of lamb meat defatted dry mass derived from animals reared in different regions in Europe (from Camin et al. (2007)). 
Table 1

Stable isotope values (mean \pm standard deviation) for authentic Irish $(\mathrm{n}=56)$ and non-Irish $(\mathrm{n}=50)$ chicken samples $(\mathrm{Monahan}$ et al., unpublished data).

\begin{tabular}{|c|c|c|c|c|c|}
\hline Sample origin & $\delta^{2} \mathrm{H}[\% 0]$ & $\delta{ }^{13} \mathrm{C}[\% 0]$ & $\delta^{15} \mathrm{~N}[\% 0]$ & $\delta^{18} \mathrm{O}[\% 0]$ & $\delta^{34} \mathrm{~S}[\% 0]$ \\
\hline Irish & $-121.7 \pm 3.5$ & $-24.7 \pm 0.5$ & $2.2 \pm 0.2$ & $15.6 \pm 0.9$ & $6.3 \pm 0.8$ \\
\hline Non-Irish & $-129.0 \pm 4.1$ & $-23.2 \pm 0.7$ & $2.2 \pm 0.3$ & $14.3 \pm 0.9$ & $5.6 \pm 1.3$ \\
\hline
\end{tabular}

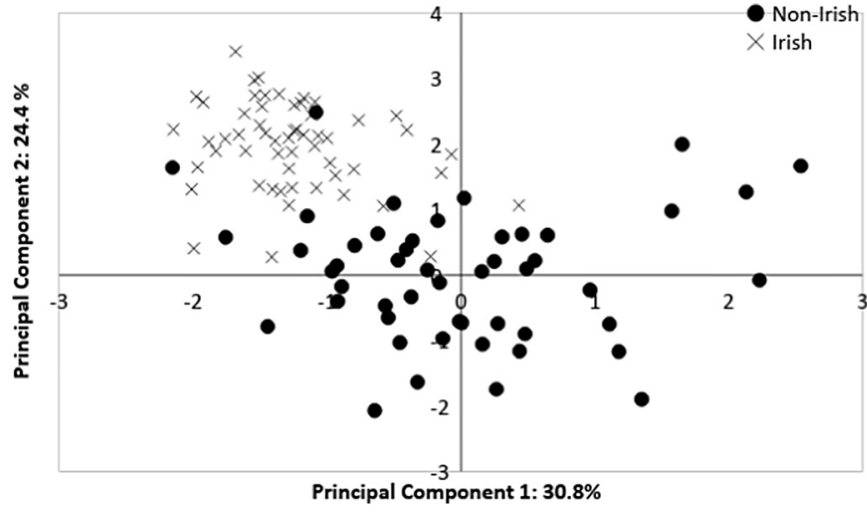

Fig. 7. Plot of the first and second principal component using all five stable isotope ratios. The two principal components extracted from the dataset explained $55.2 \%$ of the variation observed in the data. Principal component 1 (PC1) accounted for $30.8 \%$ of variation, while principal component 2 (PC2) explained 24.4\%. PC1 was mainly loaded positively with $\delta^{15} \mathrm{~N}$ and $\delta^{13} \mathrm{C}$ and negatively with $\delta^{34} \mathrm{~S}$ while PC2 was loaded positively with $\delta^{18} \mathrm{O}$ and $\delta^{2} \mathrm{H}$ (Monahan et al., unpublished data).

Table 2

Results of the re-classification of Irish and non-Irish chicken according to the linear discriminant function calculated from $\mathrm{H}, \mathrm{C}, \mathrm{N}, \mathrm{O}$ and $\mathrm{S}$ stable isotope ratios (Monahan et al., unpublished data).

\begin{tabular}{|c|c|c|c|c|c|}
\hline \multicolumn{6}{|c|}{ Classification results $^{\mathrm{a}, \mathrm{b}}$} \\
\hline & & \multirow[t]{2}{*}{ Origin } & \multicolumn{2}{|c|}{ Predicted group membership } & \multirow[t]{2}{*}{ Total } \\
\hline & & & Non-Irish & Irish & \\
\hline \multirow[t]{4}{*}{ Original } & Count & Non-Irish & 48 & 2 & 50 \\
\hline & & Irish & 2 & 54 & 56 \\
\hline & $\%$ & Non-Irish & 96.0 & 4.0 & 100.0 \\
\hline & & Irish & 3.6 & 96.4 & 100.0 \\
\hline \multirow[t]{4}{*}{ Cross-validated $^{\mathrm{c}}$} & Count & Non-Irish & 47 & 3 & 50 \\
\hline & & Irish & 2 & 54 & 56 \\
\hline & $\%$ & Non-Irish & 94.0 & 6.0 & 100.0 \\
\hline & & Irish & 3.6 & 96.4 & 100.0 \\
\hline
\end{tabular}

a $96.2 \%$ of original grouped cases correctly classified.

b $95.2 \%$ of cross-validated grouped cases correctly classified.

c Cross validation was done only for those cases in the analysis. In cross validation, each case is classified by the functions derived from all cases with that case excluded.

(Montgomery, Evans, \& Wildman, 2006; Rummel, Hoelzl, Horn, Rossmann, \& Schlicht, 2010). Franke, Koslitz, et al. (2008) investigated the usefulness for assignment of geographical origin of measuring ${ }^{18} \mathrm{O} /{ }^{16} \mathrm{O}$ in the water fraction and ${ }^{87} \mathrm{Sr} /{ }^{86} \mathrm{Sr}$ in the ash fraction of chicken and dried beef. They concluded that with $\delta^{18} \mathrm{O}$ values it was possible to distinguish poultry and dried beef samples according to their country of origin but that the discriminative power of the Sr isotopes for country of origin was low for poultry and even lower for beef. In other work on the use of $\mathrm{Sr}$ isotope ratios for geographical assignment of European beef, challenges associated with $\mathrm{Sr}$ isotope analysis in meat matrices were highlighted (Rummel et al., 2012). Furthermore, the authors point out that often animal feed is not grown locally and therefore the link to local geology is lost.
In the United Kingdom, SIRA of light $\left({ }^{2} \mathrm{H} /{ }^{1} \mathrm{H},{ }^{13} \mathrm{C} /{ }^{12} \mathrm{C},{ }^{15} \mathrm{~N} /{ }^{14} \mathrm{~N}\right.$, $\left.{ }^{34} \mathrm{~S} /{ }^{32} \mathrm{~S}\right)$ and heavy $\left({ }^{206} \mathrm{~Pb} /{ }^{207} \mathrm{~PB},{ }^{208} \mathrm{~Pb} /{ }^{207} \mathrm{~PB},{ }^{208} \mathrm{~Pb} /{ }^{206} \mathrm{~PB},{ }^{87} \mathrm{Sr} /{ }^{86} \mathrm{Sr}\right)$ elements has been used to create an isotope landscape map (isoscape) for beef (Donarski \& Heinrich, 2016). Using the data a web-based tool has been developed with the ultimate aim of being able to detect fraudulent labelling and to discriminate between beef produced in different regions of the U.K., e.g. Scottish and Welsh beef (both of which have PGI status) and beef from other jurisdictions. A similar approach may be usefully applied to protect other meats with region-specific labels of which there are many (EC, 2018).

\subsection{Challenges in interpretation of stable isotope data from animal tissues}

While the value of SIRA in the determination of the dietary background or geographical origin of meat is now well established some important issues need to be considered in the interpretation of the data. Firstly, animal diets, and the subsequent isotopic signature of meat, may vary across the animal's lifetime as availability or cost of feedstuffs changes or as the isotopic signature of a particular feedstuff, e.g. pasture, changes seasonally (Osorio et al., 2011a). In Ireland, for example, where ruminant meat production would in general be considered "grass-based", seasonal variation in stable isotope ratios in meat exists, due to dietary inclusion of non-grass components such as maize/maize silage, particularly in the winter months when animals may be housed (Bahar et al., 2008; Schmidt et al., 2005). Indeed seasonal variation in ${ }^{13} \mathrm{C} /{ }^{12} \mathrm{C}$ was shown to be lower in organic beef compared to conventionally produced beef and this was attributed to the lower likelihood of maize inclusion in winter diets in organic production systems compared to conventional systems (Bahar et al., 2008). The challenge to determination of dietary background or geographical origin of changes to the animal's diet over its lifetime is likely to be greater in systems for raising chickens, pigs or feedlot cattle, in which feed may be sourced across different jurisdictions and may not necessarily be connected to geographic location, as would be the case, for example, with grazing animals.

A second important consideration is the time taken for the isotopic composition of meat to reflect changes in the isotopic composition of the diet, for example in situations where the diet changes due to seasonal factors or there is a switch in dietary constituents prior to slaughter. Using SIRA it is possible to determine the time taken for changes in animal diet to be reflected in the meat (Bahar et al., 2005, 2009; Harrison et al., 2007). It is well established that beef from animals fed diets containing $\mathrm{C}_{4}$ plant material (e.g. maize) can be clearly differentiated from beef from animals fed $\mathrm{C}_{3}$ plant material (e.g. temperate grass, barley) (Boner \& Förstel, 2004; De Smet, Balcaen, Claeys, Boeckx, \& Van, 2004; Gebbing, Schellberg, \& Kühbauch, 2004) and this difference can be useful in discriminating between meat from different regions of the world where production systems differ (Guo et al., 2010; Nakashita et al., 2008; Rossmann \& Schlicht, 2007; Schmidt et al., 2005). From the stable isotope data of muscle from beef cattle fed either grass silage $\left(\mathrm{C}_{3}\right)$ or maize silage $\left(\mathrm{C}_{4}\right)$ or a 50:50 (DM basis) mixture of both for 167 days, Bahar et al. (2005) estimated that each $10 \%$ change in dietary $\mathrm{C}_{4}$ carbon (from maize) would resulted in a 0.9 to $1.0 \%$ shift in the $\delta^{13} \mathrm{C}$ value of muscle. While the animals in this latter study were fed the contrasting diets for 167 days pre-slaughter, the time taken for the different diets to be fully reflected in isotope ratios in meat is unknown, i.e. how long does it take for $\mathrm{C}$ or $\mathrm{N}$ in muscle to fully turn over in response to a diet switch? To address this question, beef cattle were 


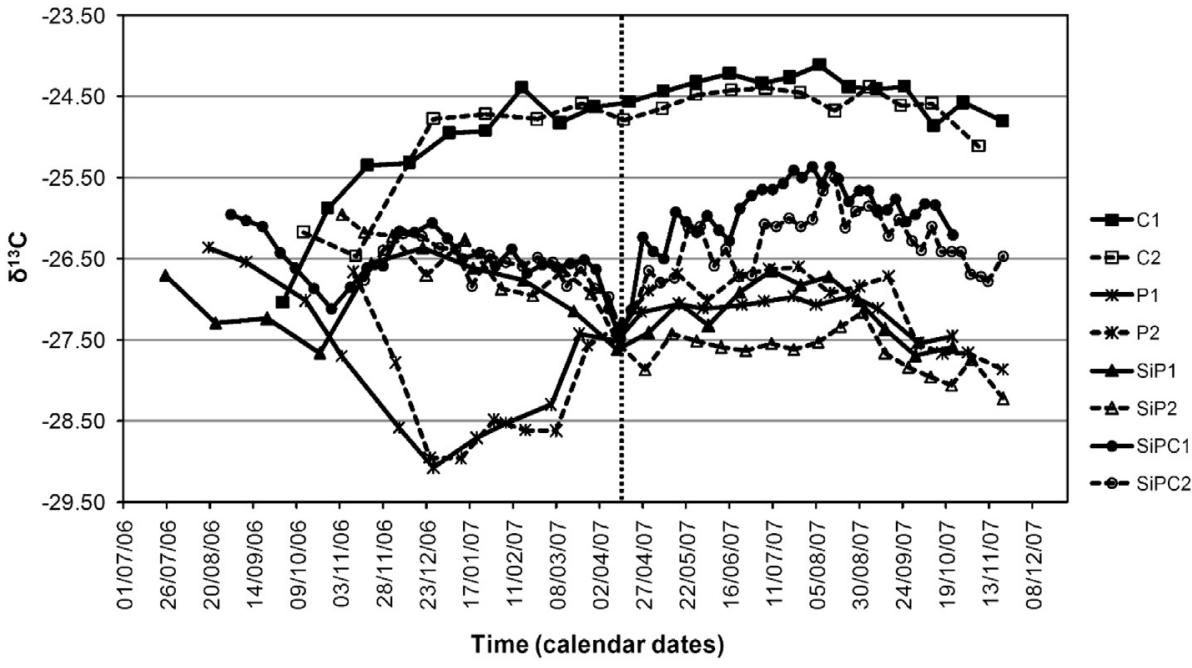

Fig. 8. Temporal changes in tail hair $\delta^{13} \mathrm{C}$ of animals from four dietary treatments. C1 and C2 represent tail hair samples from two animals fed a cereal concentrate-based diet (C) with an experimental start date of 12 December 2006 and slaughter dates of 21 November 2007 and 7 November 2007, respectively. P1 and P2 represent tail hair from two animals fed entirely at pasture (P) with an experimental start date of 28 November 2006 and slaughter dates of 23 October 2007 and 21 November 2007, respectively. SiP1 and SiP2 represent tail hair from two animals with an experimental start date of 28 November 2006, fed grass silage (Si) indoors and switched to grass at pasture (P) outdoors on 18 April 2007, and with slaughter dates of 23 October 2007 and 21 November 2007, respectively. SiPC1 and SiPC2 represent tail hair from two animals with an experimental start date of 28 November 2006, fed grass silage (Si) indoors and switched to pasture (P) with a concentrate (C) supplement outdoors on 18 April 2007, and with slaughter dates of 23 October 2007 and 21 November 2007, respectively. The vertical dash line indicates the diet switch (18 April 2007) in the case of the SiP and SiPC animals (from Osorio et al. (2011a)).

switched from a barley grain $\left(\mathrm{C}_{3}\right)$ to a maize grain $\left(\mathrm{C}_{4}\right)$-based diet for periods ranging from 2 to 22 weeks pre-slaughter and, from the isotope data obtained, half-lives of 151 and 157 days for $\mathrm{C}$ and $\mathrm{N}$ in longissimus thoracis et lumborum muscle were calculated, respectively (Bahar et al., 2009). In lamb, shorter half-lives with values of $\sim 76$ days for $C$ in longissimus thoracis et lumborum muscle were calculated (Harrison et al., 2011).

\subsection{Stable isotope analysis of incremental tissues}

Although SIRA of meat (muscle and adipose tissues mainly) is very useful for obtaining information about pre-slaughter origin (dietary and geographical), the stable isotope ratios measured in these tissues represent an "integrated" signature of the dietary inputs over a period of time pre-slaughter and, therefore, short-term changes to the diet may go undetected (Bahar et al., 2009; Sponheimer et al., 2006). If grass-fed animals receive non-grass feed inputs, a cereal concentrate for example, for a period of time pre-slaughter, this may not be detectable either because tissue turnover rate is not fast enough to elicit a response in meat or because the stable isotope signature of the cereal concentrate is insufficiently different from that of the pasture to elicit a response in the animal tissue (Bahar et al., 2009; Harrison et al., 2011). A powerful approach to reconstructing changes in diet over an animal's lifetime is the use of incremental tissues such as hair (Schnyder, Schwertl, Auerswald, \& Schaeufele, 2006; Schwertl, Auerswald, Schäufele, \& Schnyder, 2005; West et al., 2004), hoof (Harrison et al., 2007; Zazzo et al., 2007), or wool (Zazzo et al., 2011; Zazzo, Moloney, Monahan, Scrimgeour, \& Schmidt, 2008), which contain a record of changes to diet over time. Incremental tissues such as these are metabolically inert tissues that are progressively laid down and then remain unchanged, so that the isotope ratios and, thus, information about the diet assimilated at the time of tissue growth, are preserved during their growth (Barbosa et al., 2009; Hobson, 1999). While such incremental tissues are not available at the point of sale of meat cuts, they can usually be sampled easily when meat is still on the carcass or (in the case of hair) from live animals whose origin is questioned.

Sequential isotopic analysis of short sections (5-10 mm) of cattle tail hair yielded an isotopic archive of temporal and seasonal fluctuations in the isotopic composition of diet (Schwertl, Auerswald, \& Schnyder, 2003). Shifts from a barley concentrate $\left(C_{3}\right)$ diet to a maize $\left(C_{4}\right)$ diet were clearly evident from stable isotope analysis of hair (Zazzo et al., 2007) and hoof (Harrison et al., 2007) of cattle and of wool of sheep (Zazzo et al., 2008). Interestingly, from a forensic perspective, an unplanned change in the diet of cattle on a maize-based diet was detected using stable isotope analysis of tail hair (Zazzo et al., 2007).

Apart from detection of changes to diet over time, isotopic signatures of metabolically inert tissues can also be used for discrimination purposes. Moreno-Rojas et al. (2008) reported discrimination between lambs fed three different diets (herbage, barley and maize-based concentrate) on the basis of $\delta^{13} \mathrm{C}$ and $\delta^{15} \mathrm{~N}$ values of wool. Zazzo et al. (2011) demonstrated a clear relationship between $\delta^{34} S$ values of sheep's wool and distance from the sea in Ireland with potential application in geographical assignment. Liu, Guo, Wei, Shi, and Sun (2013) investigated the applicability of measurement of $\delta^{13} \mathrm{C}, \delta^{15} \mathrm{~N}$ and $\delta^{2} \mathrm{H}$ values in 167 cattle tail hair samples, obtained from 7 regions and 4 beef production regions in China, to discriminate on the basis of geographical origin and production system.

While many studies have demonstrated the clear effect of a change from a $\mathrm{C}_{3}$ (e.g. grass or barley) to a $\mathrm{C}_{4}$ (e.g. maize) diet, or vice versa, in stable isotope signatures of integrating and incremental tissues (Moreno-Rojas et al., 2008), detecting a change in diet between isotopically similar feedstuffs (e.g. between $\mathrm{C}_{3}$ feedstuffs such as barley and grass or herbage (Monahan et al., 2006; Moreno-Rojas et al., 2008) can be more challenging. Using tail hairs from animals on four different $\mathrm{C}_{3}$ dietary treatments, Osorio et al. (2011a) measured $\delta^{13} \mathrm{C}$ and $\delta^{15} \mathrm{~N}$ values in mm segments of hair sampled sequentially; the segment of tail hair at the follicular end contained a record of dietary $\delta^{13} \mathrm{C}$ and $\delta^{15} \mathrm{~N}$ values close to the time of slaughter and the hair tip contained a record of diet up to, or more than, a year earlier, depending on the hair length. The $C$ isotopic signatures of consecutive hair segments from two different animals from each of the four treatment groups are shown in Fig. 8. At the time of slaughter, the $\delta^{13} \mathrm{C}$ values of tail hair from the different groups reflected those of the diets and muscle at that time, with the grass-fed groups having the more negative $\delta^{13} \mathrm{C}$ values, the concentrate-fed group having the least negative values and the group fed both grass and a barley concentrate having intermediate values (Fig. 8). Tail hairs from animals subjected to a diet switch are of particular interest from a diet reconstruction perspective because both preand post-switch diets were isotopically close in value. The switch in diet, from grass silage to grass at pasture, or from grass silage to grass at pasture with a supplement of cereal concentrate, occurred 5 months after the start of the experiment. In both groups, the diet switch was indicated by an inflection in the $\delta^{13} \mathrm{C}$ signature of sequentially analysed tail hair segments and an adjustment of the $\delta^{13} \mathrm{C}$ values thereafter to those of the new diets (Fig. 8). The $\delta^{15} \mathrm{~N}$ values of tail hair samples were similarly useful in identifying the diet switch (Osorio et al., 2011a). 


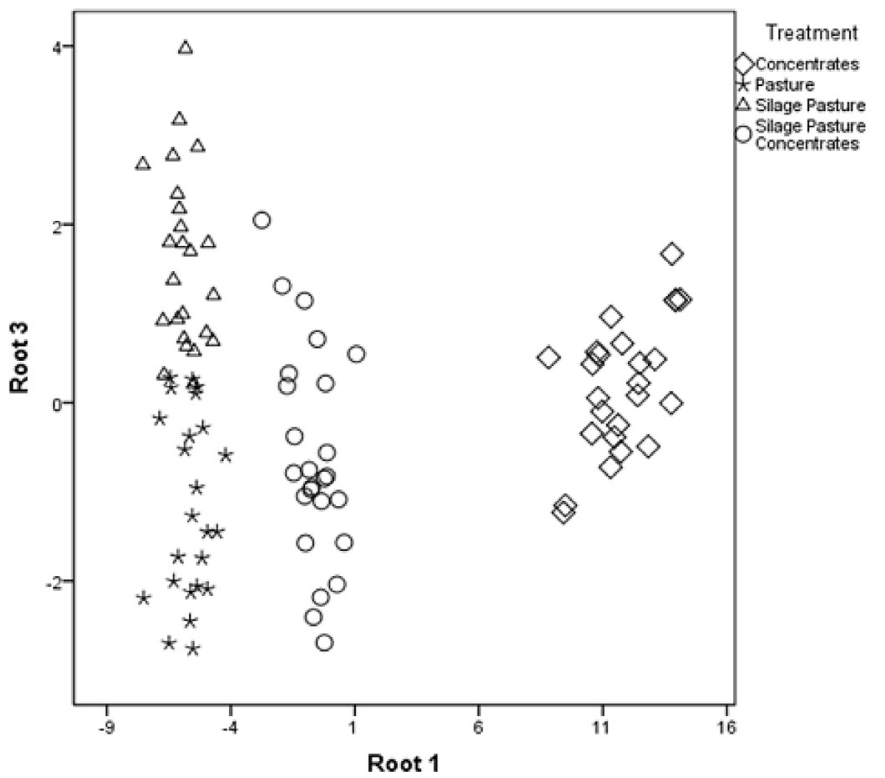

Fig. 9. Plot of the discriminant functions for classification of beef according to production system, based on muscle fatty acid analysis. The production systems were for cattle fed as follows: grass at pasture for 12 months (Pasture); grass silage for 6 months followed by grass at pasture for 6 months (Silage Pasture); grass silage for 6 months followed by grass at pasture with a barley-based concentrate ( 0.5 of total dry matter) for 6 months (Silage Pasture Concentrates); or a barley-based concentrate for 12 months (Concentrates) (Monahan et al., unpublished data).

A recent isotope tracer study by Bechshøft, Schjerling, Bornø, and Holm (2017) showed that there are protein fractions (in connective tissue in the eye lens and patellar tendon) in mature rats that had very slow turnover during the rats' lives. That finding opens the prospect that there could be soft tissue components (rather than incremental tissues) that preserve isotopic life-history information in livestock animals.

\section{Trace and rare earth elements}

Measurement of trace elements either alone or in combination with other measurements, including SIRA, has also shown potential in dietary background and geographical origin assignment. Franke, Hadorn, et al. (2008) investigated trace element analysis together with measurement of $\delta^{18} \mathrm{O}$ for country of origin assignment of beef and poultry meat. Combining the data from three studies (Franke et al., 2007; Franke, Haldimann, et al., 2008; Franke, Koslitz, et al., 2008) these authors obtained country of origin predictions with cross-validation and validation outputs of $83 \%$ and $50 \%$ correct classifications, respectively, for poultry and $73 \%$ and $43 \%$, respectively, for beef.

In Chinese beef samples, Zhao et al. (2013) measured the concentration of 23 trace elements using ICP-MS and ${ }^{13} \mathrm{C} /{ }^{12} \mathrm{C}$ and ${ }^{15} \mathrm{~N} /{ }^{14} \mathrm{~N}$ isotope ratios using IRMS. Concentrations of $\mathrm{Mg}, \mathrm{K}, \mathrm{Mn}, \mathrm{Zn}, \mathrm{Se}$, and $\mathrm{Zr}$ together with $\delta^{13} \mathrm{C}$ and $\delta^{15} \mathrm{~N}$ values were selected to establish a classification model using a stepwise discriminant procedure. The authors achieved $100 \%$ correct classification although this is probably not surprising given the wide geographical spread of the four sample locations and the likely diversity in feed inputs and underlying geology. A similar approach was taken for chicken from four locations in China with a similar outcome in terms of sample classification (Zhao, Zhang, Guo, Wang, \& Yang, 2016). Rees et al. (2016), using multivariate analysis of 31 variables ( 5 isotopic parameters and concentrations of 26 elements: $\delta^{2} \mathrm{H} \% 0, \delta^{13} \mathrm{C} \%$, $\delta^{15} \mathrm{~N} \% 0, \delta^{18} \mathrm{O} \%$, $\delta 34 \mathrm{~S} \%$, Li, Be, B, Na, Mg, $\mathrm{Al}, \mathrm{Ca}, \mathrm{Cr}, \mathrm{Mn}, \mathrm{Fe}, \mathrm{Co}, \mathrm{Ni}, \mathrm{Cu}, \mathrm{Zn}, \mathrm{Ga}, \mathrm{As}, \mathrm{Se}, \mathrm{Rb}, \mathrm{Sr}, \mathrm{Mo}, \mathrm{Ag}, \mathrm{Cd}, \mathrm{Te}, \mathrm{Ba}$, $\mathrm{Tl}$ and $\mathrm{Pb}$ ), obtained correct classification rates of $100 \%, 94.1 \%, 92 \%$, $82.6 \%, 70.3 \%$ and $50 \%$ for chicken samples from China $(n=36)$, Brazil
( $n=101)$, Europe $(n=87)$, Chile $(n=46)$, Thailand $(n=46)$ and Argentina $(n=10)$, respectively. One example for country of origin of pork is the survey by Kim et al. (2017) who measured 29 macro and trace elements in samples from Korea, the USA and 4 European countries, using inductively coupled plasma-optical emission spectroscopy (ICP-OES) and ICP-MS. While linear discriminant analyses of multielemental data separated Korean pork samples $(97 \%$ discrimination index), the study illustrates the lack of mechanistic explanatory power of the trace element approach.

Danezis et al. (2017), in a game meat application, point to the additional potential offered by rare earth elements which, with advances in instrumental sensitivity, are now more readily quantifiable and may be of value in meat authentication. They could distinguish wild game (rabbit) meat from farmed game as well as temporal variation in samples.

\section{Determination of specific compounds in meat as indicators of dietary background}

The relationship between the diet of animals and the concentration of nutrients such as fatty acids, carotenoids and vitamin $\mathrm{E}$ in meat is long established. Among the motivations for the many studies in this area, across all meat species, is the profound impact that the diet of animals can have on the nutritional and sensory quality of meat (Scollan et al., 2014; Woods \& Fearon, 2009). From a nutritional perspective, for example, beef from grass-fed animals has been shown to have elevated levels of n-3 fatty acids, conjugated linoleic acid, carotenoids and vitamin E compared to beef from cereal-fed animals (Daley et al., 2010). From a sensory perspective, increased polyunsaturated fatty acids (PUFA) in the diet of meat producing animals can lead to increased PUFA in meat, especially in non-ruminants, with consequences for the subsequent oxidative stability, flavour (including off-flavour) development and colour stability of the meat (Scollan et al., 2014). Increased levels of dietary vitamin $E$ lead to increased oxidative stability (Luciano et al., 2011) while dietary carotenoids affect meat fat colour (Dunne, Monahan, O'Mara, \& Moloney, 2009).

\subsection{Fatty acids}

In terms of verification of the dietary background of animals it is useful to determine if the nutrient composition of meat (fatty acids, carotenoids, vitamin E, etc) is consistent with consumption of a particular diet or with a particular production system. As an example, the potential for discrimination between grass- and cereal-fed beef by measurement of these nutrients has been investigated. Alfaia et al. (2009) successfully used fatty acid analysis to discriminate between animals fed a barley-based concentrate diet in a feedlot, pasture-fed animals or pasture-fed animals subsequently fed the barley-based for two or four months pre-slaughter. Similarly, we sought to discriminate, using fatty acid analysis, between beef from animals raised on grass at pasture, a barley-based concentrate or on grass/concentrate combinations (Fig. 9). The discrimination model obtained, with leave-one-out cross-validation, permitted differentiation into the four dietary treatments with a correct classification of $92.9 \%$. The miss-classified samples related to beef from animals raised on pasture for 12 months prior to slaughter being classified as beef from animals fed grass silage for 6 months followed by grass at pasture for 6 months. Effectively, however, both groups could be considered grass-fed, since the silage is ensiled grass, and therefore the miss-classification was not of major significance from the perspective of grass-fed beef authentication; pooling these groups together gave $100 \%$ correct classification of beef according to diet. Monteiro, Fontes, Bessa, Prates, and Lemos (2012) reported a correct classification, after cross validation, of $82-87 \%$ for veal calves reared according to the local PGI and PDO rules while Dias et al. (2008) reported a correct classification, without cross validation, of $100 \%$ for beef produced according to a "traditional" or organic 
production system. These studies and that of Moloney, O'Riordan, Schmidt, Monahan (2018) demonstrate that relatively small differences in the fatty acid profile can also be used to distinguish beef produced from different sward types. Oliveira, Alewijn, Boerrigter-Eenling, and van Ruth (2015) achieved a high level of discrimination between organic and non-organic pork using fatty acid analysis followed by PCA and soft independent modelling of class analogy (SIMCA) classification.

\subsection{Vitamin E stereoisomers}

Analysis of vitamin E stereoisomers in food of animal origin can yield information about the sources of vitamin $\mathrm{E}$ - natural or synthetic in the diet of animals (Meglia, Jensen, Lauridsen, \& Waller, 2006). Röhrle, Moloney, Black, et al. (2011) investigated, using analysis of vitamin E stereoisomers, the potential to distinguish between beef from animals receiving vitamin $\mathrm{E}$ from natural sources only (grass-fed beef) and beef from animals receiving a synthetic vitamin E supplement. The data showed that in muscle from grass-fed beef cattle the RRR stereoisomer of $\alpha$-tocopherol dominated, while in beef from concentrate-fed animals receiving a vitamin/mineral supplement there was evidence of all eight stereoisomeric forms of $\alpha$-tocopherol being present, consistent with synthetic vitamin E supplementation (Fig. 10). Beef samples sourced from retail outlets, some with background information declared (e.g. pasture-fed or organic) and others of unknown dietary background, were also analysed (Röhrle, Moloney, Black, et al., 2011). In some instances there was evidence of synthetic vitamin E supplementation, in others not.

\subsection{Carotenoids}

Prache and Theriez (1999) investigated whether carotenoids, measured directly in plasma or indirectly via the reflectance spectra of adipose tissue could be used to trace lamb production system, particularly grass feeding. In this and subsequent studies carotenoid measurement was established as a method for discriminating pasture-fed lambs from concentrate-fed lambs (Dian, Chauveau-Duriot, Prado, \& Prache, 2007; Priolo, Prache, Micol, \& Agabriel, 2002). In agreement with the work of Prache and co-workers, research on beef in our group showed contrasting reflectance spectra $(400-700 \mathrm{~nm})$ for subcutaneous adipose tissue from animals fed pasture versus a barley-based concentrate for a 12 month period (Röhrle, Moloney, Osorio, et al., 2011). Furthermore, subcutaneous adipose tissue from a group fed silage for 6 months followed by pasture for 6 months was distinguishable from

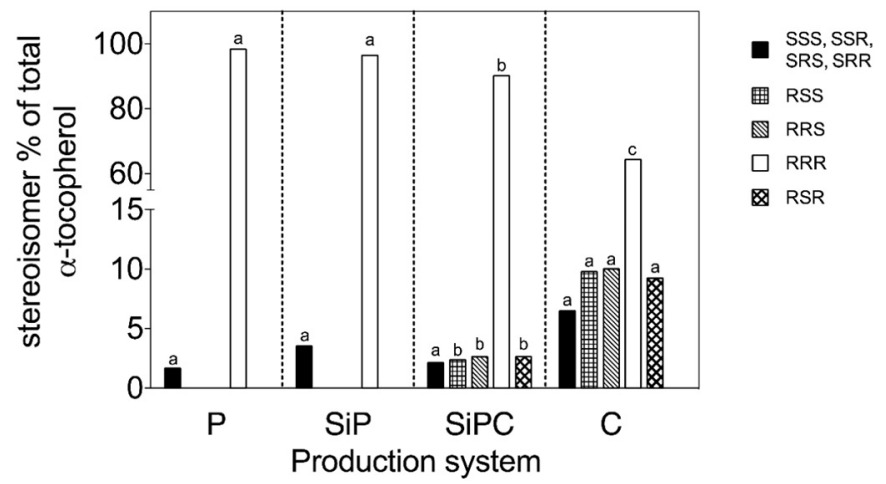

Fig. 10. Stereoisomers of $\alpha$-tocopherol (\% of total) in muscle from cattle fed grass at pasture for 12 months (P), grass silage for 6 months followed by grass at pasture for 6 months (SiP), grass silage for 6 months followed by grass at pasture supplemented with a barley-based concentrate ( 0.5 of total dry matter) for 6 months (SiPC) or a barley-based concentrate for 12 months (C) Between production system treatments, bars for the same stereoisomer with different letters ( $a, b, c)$ are significantly different $(P<0.05)$ (from Röhrle, Moloney, Black, et al. (2011). that of the group fed pasture for 12 months, indicating an effect of a diet consumed 6 months pre-slaughter on adipose tissue reflectance at slaughter (Fig. 11). For a group fed silage for 6 months followed by a 50:50 (DM basis) pasture/concentrate mixture for 6 months the influence of inclusion of a proportion of concentrate clearly affected the reflectance spectra.

\subsection{Volatile compounds}

Gas chromatographic methods have been applied to the measurement of the volatile profile of meats. Among the meat volatile components influenced by diet, particularly grass versus concentrate feeding, are branched chain fatty acids, lactones, aldehydes, phenolic compounds, indoles, 2,3-octanedione, terpenes and sulphur compounds (Vasta \& Priolo, 2006). Of these compounds some are directly incorporated into tissues from the diet while others, for example certain sulphur compounds and lipid oxidation products, are indirect markers of dietary background because they are generated by reactions, involving the absorbed dietary compounds, that occur during cooking of meat fat. Vasta, Ratel, and Engel (2007), using dynamic headspace GC-MS, identified 33 significant compounds (from a total of 114) which contributed to discrimination of concentrate versus pasture-fed lambs. A study of beef from animals raised at pasture, on concentrates or on grass silage/pasture/concentrate combinations identified skatole, 3-undecanone, cuminic alcohol and 2 methyl-1-butanol as compounds that allowed discrimination between beef from animals fed concentrates and from animals fed non-concentrate diets (Vasta et al., 2011) (Fig. 12). Germacrene D, a terpenoid, was a marker of grass feeding. Serrano, Cornu, Kondjoyan, Agabriel, and Micol (2011) reported complete separation of suckling bulls supplemented with hay, cut green herbage or grazed pasture by measuring 2,3-octanedione, skatole and terpenes in adipose tissue.

Like fatty acids, the terpene profile of feedstuffs can vary with plant species and stage of growth (Mariaca et al., 1997; Tornambé et al., 2006) and this poses challenges in establishing a consistent relationship between feed consumed and the profile in meat. In addition, terpene enrichment in ruminant lipids may not be uniform across different lipid fractions and, thus, the selection of particular lipid fractions may be important in distinguishing between feeding systems (Serrano et al., 2007).

\subsection{Diet switches and tissue turnover of dietary markers}

Similar to the use of stable isotopes in the determination of dietary background, the confounding effect of diet switches on classification using other potential markers is recognised. For instance, Prache et al. (2003a) showed that following a switch from pasture to concentrates, plasma carotenoids decreased over a 13 day period in lambs. The implication was that following a switch from grass to concentrates, grazing lambs would be considered "pasture-fed" if plasma carotenoids were measured for up to 13 days after the switch and "concentrate-fed" if plasma carotenoids were measured thereafter. A further confounding effect identified by Prache, Priolo, and Grolier (2003b) is that depletion of carotenoids in adipose tissue, after a change to a low carotenoid diet, occurs due to a dilution of existing adipose tissue by new adipose tissue; thus, in mature animals carotenoid measurement in adipose tissue may not be an appropriate indicator of diet.

In the case of the other marker compounds discussed above (fatty acids, vitamin E, volatile organic compounds) similar challenges with respect to diet switches and tissue turnover also clearly exist. For fatty acids in beef, for example, Noci, Monahan, French, and Moloney (2005) demonstrated a gradual linear increase in conjugated linoleic acid and a decrease in $n-6 / n-3$ fatty acid ratio when animals were switched from a grass silage/concentrate-based diet to grass at pasture for periods of 40 , 99 or 158 days pre-slaughter. In pork, vitamin $\mathrm{E}$ uptake in tissues in response to a switch to a high vitamin $\mathrm{E}$ diet was found to be in the 


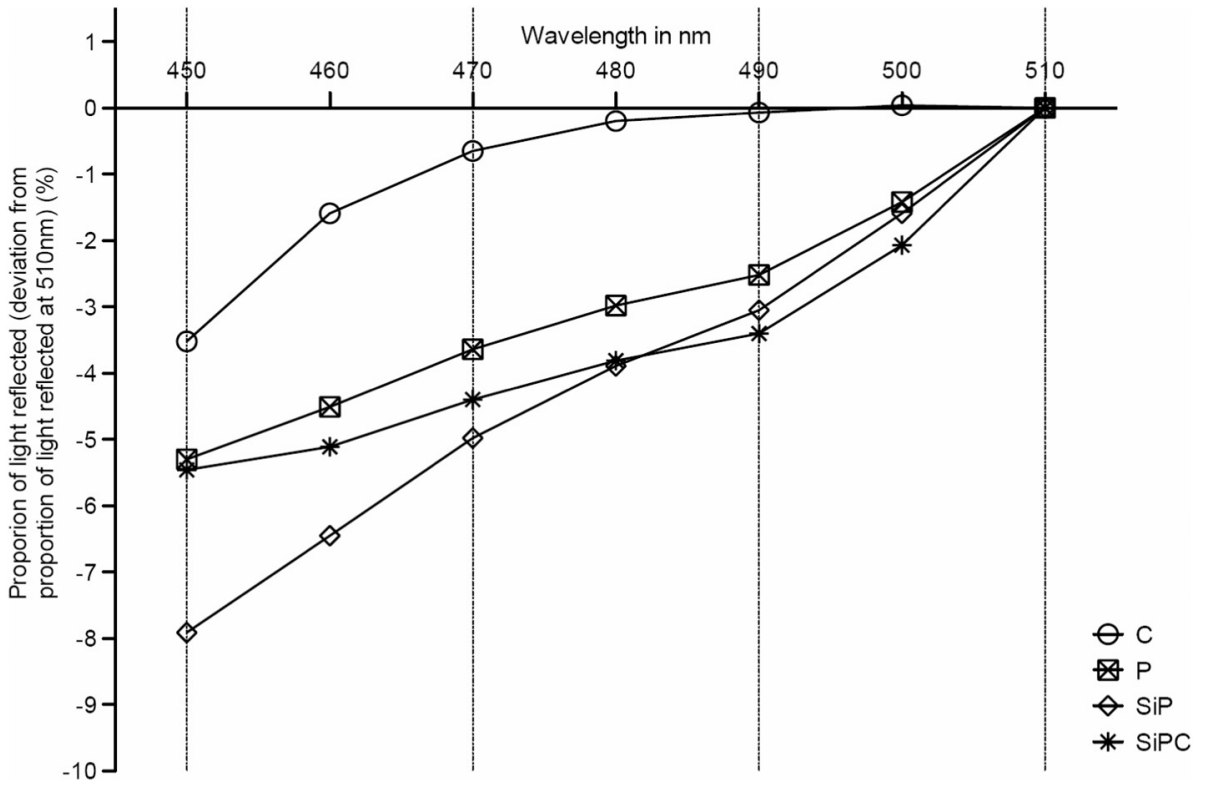

Fig. 11. Mean reflectance spectra of subcutaneous adipose tissue of beef cattle fed grass at pasture for 12 months (P), grass silage for 6 months followed by grass at pasture for 6 months (SiP), grass silage for 6 months followed by grass at pasture supplemented with a barley-based concentrate ( 0.5 of total dry matter) for 6 months (SiPC) or a barley-based concentrate for 12 months (C) (from Röhrle, Moloney, Osorio, et al. (2011).

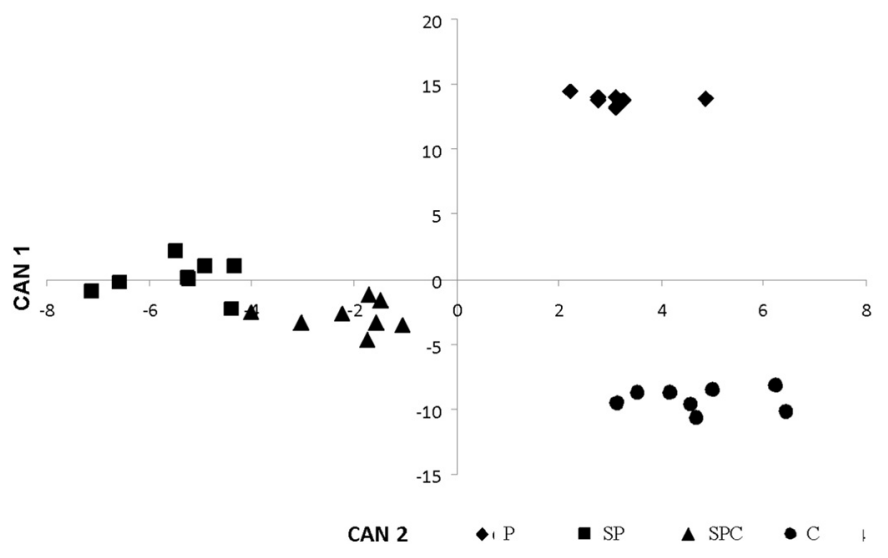

Fig. 12. Discrimination of dietary background on the basis of canonical discriminant analysis using 16 volatile organic compounds identified in beef from animals fed grass at pasture for 12 months (P); grass silage for 6 months followed by grass at pasture for 6 months (SP); grass silage for 6 months followed by grass at pasture supplemented with a barley-based concentrate ( 0.5 of total dry matter) for 6 months (SPC); or a barley-based concentrate for 12 months (C) (from Vasta et al. (2011).

order blood $>$ liver $>$ muscle $>$ adipose tissue (Monahan, Buckley, Morrissey, Lynch, \& Gray, 1990). A further limitation to the use of fatty acid profile as an indicator of grass-based production is that non-grass sources of fatty acids could give 18:3 n-3, 18:2 n-6 or CLA contents in meat similar to those derived from grass (Shingfield, Bonnet, \& Scollan, 2013).

In the context of the difficulty of detecting changes to the diet of animals, and in the absence of approaches like stable isotope analysis of incremental tissues, analysis of nutrients such as fatty acids and vitamins may be more usefully applied to the identification of meat samples that are not consistent with a particular mode of production. In other words, while it may be difficult to conclude definitely, using fatty acid or volatile profile analysis, that beef is grass-fed from Australia, Brazil or Ireland for example, it may be possible to identify profiles that are not consistent with grass-fed beef production.
5. Methods with future potential in meat authentication

\subsection{Nuclear magnetic resonance (NMR)}

With a small sample set (23), Shintu, Caldarelli, and Franke (2007) demonstrated the potential of NMR to assign geographical origin to dried beef samples from 5 countries. Subsequently, Osorio, Moloney, Brennan, and Monahan (2012) used ${ }^{1} \mathrm{H}$ NMR to investigate changes in the metabolomic composition of bovine urine and muscle as a potential approach to discriminating between different beef production systems. Using partial least squares-discriminant analysis, pairwise comparisons performed on ${ }^{1} \mathrm{H}$ NMR data from the urine samples showed good discrimination of animals fed grazed grass at pasture from those fed a barley-based concentrate, with urinary creatinine, glucose, pyruvate, phenylalanine and hippurate being identified as discriminating variables. Discrimination between muscle from animals grazing grass at pasture and animals fed the barley based concentrate was also possible although the model was not as strong as for urine. Among the discriminating metabolites were carnosine, which was higher, and methylhistidine, malonate, glutamine, which were lower, in muscle from animals fed a barley-based concentrate (Osorio et al., 2012).

\subsection{Spectroscopic techniques}

Near and mid infra-red spectroscopy (NIRS and MIRS, respectively) has also shown promise as a tool for authenticating the dietary background of meat. Dian, Andueza, Jestin, Prado, and Prache (2008) examined the spectrum of perirenal fat at between 400 and $2500 \mathrm{~nm}$ and reported that the longer wavelength range produced models of higher discriminant ability giving correct classification rates of $97.7 \%$ between pasture-fed and concentrate-fed lamb. Subsequently, Huang, Andueza, de Oliveira, Zawadzki, and Prache (2015) reported that using a similar wavelength spectrum, perirenal fat from pasture-fed, concentrate-fed and concentrate-finished after pasture feeding could be distinguished with a correct classification of $98.6 \%, 100.0 \%$ and $98.5 \%$, respectively. There are relatively few reports on the utility of NIRS for authenticating dietary background when applied to meat rather than fat. Cozzolino, De Mattos, and Martins (2002) (2012) reported correct classification of $82 \%$ and $79 \%$ of samples from cattle finished on pasture or on a maize silage ration, respectively. More recently, NIRS was used to discriminate between samples of light lamb finished on concentrates but whose dams grazed alfalfa, lucerne or were fed a total mixed ration 
during the weaning phase (Ripoll, Lobón, \& Joy, 2018). In contrast, visible-NIRS spectra of intact pork chops could not discriminate between pre-slaughter rations based on a commercial concentrate or that concentrate supplemented with canola or flaxseed, presumably due the relative similarity in the ration composition (Prieto et al., 2015). With regard to authentication of geographical origin, Sun, Guo, Wei, and Fan (2012) examined the potential of NIRS for authenticating lamb meat from five regions in China. Linear discriminant analysis of the spectral data allowed $100 \%$ correct classification of the samples into two major regions (defined as pastoral and agricultural). Within each region however, the discrimination was not as successful. Similarly, Erasmus, Manley, Muller, and Hoffman (2016) demonstrated the potential of NIRS when discriminating between lamb samples from different regions of South Africa. Developments in NIR and other spectral technologies such as Raman spectroscopy and hyperspectral imaging will likely result in further evaluation of spectroscopic approaches to authenticating meat provenance in the future (Lohumi, Lee, Lee, \& Cho, 2015).

\subsection{Functional genomics}

Among the more recent approaches with potential for use in discriminating between production systems is functional genomics, in particular transcriptome (Hocquette et al., 2009; Prache, 2009) and proteome (Shibata et al., 2009) profiling. Cassar-Malek et al. (2009), in a comparison of outdoor pasture vs indoor concentrate feeding of Charolais cattle, found Selenoprotein $\mathrm{W}$ to be under-expressed in pasture-fed animals and proposed it as a putative gene marker of the grassland system. Duckett, Pratt, and Pavan (2009) studied expression of genes involved in lipogenesis in muscle and found up-regulation of stearoyl-CoA desaturase, fatty acid synthase and Spot-14 and down regulation of signal transducer and activator of transcription-5 (STAT5) in the subcutaneous fat of grazing steers finished on a high-concentrate diet compared with a pasture only diet. More recently, Sweeney et al. (2016) identified 26 differentially expressed genes in a comparison of beef from outdoor/pasture-fed cattle with indoor/concentrate-fed cattle. A number of the differentially expressed genes were associated with fatty acid metabolism, some were positively correlated with n-3 fatty acid content and good discrimination of the beef on the basis of production system was achieved using normalised expression levels of three genes.

\section{Conclusion}

Among many factors such as the global nature of trade in meat, the complexities of the food chain associated with meat production, consumer demands for more information about the food they consume and the potential for fraud, there seems little doubt that meat authenticity will continue to be a subject of discussion and research into the future. The exponential growth in research on food authentication in recent years is evidence of this (Danezis et al., 2016). The research to date has engaged a range of different approaches to the challenge of developing robust methods for meat authentication. Among the successes are those associated with speciation and the detection of fraud in meat (FSA, 2013) and the development of stable isotope databases for food products (mostly non-meat) against which unknown samples may be tested (Camin et al., 2017). Global efforts are emerging for meat as well, for instance on isotopic and trace elemental data for poultry (Rees et al., 2016).

From the particular perspective of dietary background and geographical origin, it is clear that a single analyte is unlikely to be adequate and that measurement of multiple markers is required. The more successful applications of SIRA to meat authentication, for example, involve multi-element analysis combined with multi-variate statistical analysis. Determination of the dietary background and geographical origin of meat brings specific challenges not least of which is the possibility for animals to move between different jurisdictions and to consume foods from different sources and from different geographical origins over their lifetime. In this context, taking a forensic approach, analysis of incremental tissues (if available from the carcass or live animal) may be useful for retrospective determination of dietary background and geographical origin. Even within a specific geographic designation seasonal variation in feed inputs, with an ultimate effect on elemental and molecular signature in meat, needs to be considered. This may require measurement of dietary markers in a number of tissues, with different turnover rates.

This review shows that there are many examples of how various analytical techniques can be used to discriminate between meats based on different production systems or geographical origins. The approach taken to-date has been very much "proof of concept". There is a need now to extend the advances made to the development of authentication tools that can be applied to meats and meat products with specific labels based on their mode of production or geographical origin. In this context, there is a need to develop more databases for meat from particular production systems and geographical origins, against which test samples can be compared for verification purposes. The British Beef Origin Project (Donarski \& Heinrich, 2016) is a step in this direction. Challenges lie in discriminating meat samples produced in geographically close regions but, on the other hand, a maritime border, local geology or regional climatic differences are likely to increase the potential for discrimination and this could be exploited in certain jurisdictions.

\section{Acknowledgements}

The contribution of studies conducted under the EU FP6 TRACE project (project FOOD-CT-2005-006942; Tracing Food Commodities in Europe), the Food Institutional Research Measure of the Irish Department of Agriculture, Food and the Marine (project 06/R\&D/D/ 481; Biomarkers to Authenticate Irish Grass-fed Beef) and the Teagasc Walsh Fellowship programme (Determination of the Dietary Background of Beef using Stable Isotope Analysis) is gratefully acknowledged. The authors also thank Dr. Michael Salter-Townshend (UCD) for his insights into the statistical approaches adopted in the studies reviewed in the manuscript.

\section{References}

Alfaia, C. P. M., Alves, S. P., Martins, S. I. V., Costa, A. S. H., Fontes, C. M. G. A., Lemos, J. P. C., ... Prates, J. A. M. (2009). Effect of the feeding system on intramuscular fatty acids and conjugated linoleic acid isomers of beef cattle, with emphasis on their nutritional value and discriminatory ability. Food Chemistry, 114(3), 939-946.

Amaral, J., Meira, L., Oliveira, M. B. P. P., \& Mafra, I. (2016). Advances in authenticity testing for meat speciation. Advances in food authenticity testing (pp. 369-414). Elsevier.

Arvanitoyannis, I. S. (2016). Authenticity of foods of animal origin. Boca Raton, Florida, USA: CRC Press, Taylor \& Francis Group.

Bahar, B., Moloney, A. P., Monahan, F. J., Harrison, S. M., Zazzo, A., Scrimgeour, C. M., .. Schmidt, O. (2009). Turnover of carbon, nitrogen, and sulfur in bovine longissimus dorsi and psoas major muscles: Implications for isotopic authentication of meat. Journal of Animal Science, 87(3), 905-913.

Bahar, B., Monahan, F. J., Moloney, A. P., O'Kiely, P., Scrimgeour, C. M., \& Schmidt, O. (2005). Alteration of the carbon and nitrogen stable isotope composition of beef by substitution of grass silage with maize silage. Rapid Communications in Mass Spectrometry, 19(14), 1937-1942.

Bahar, B., Schmidt, O., Moloney, A. P., Scrimgeour, C. M., Begley, I. S., \& Monahan, F. J. (2008). Seasonal variation in the C, N and S stable isotope composition of retail organic and conventional Irish beef. Food Chemistry, 106(3), 1299-1305.

Ballin, N. Z. (2010). Authentication of meat and meat products. Meat Science, 86(3), 577-587.

Barbosa, I. C. R., Kley, M., Schäufele, R., Auerswald, K., Schröder, W., Filli, F., ... Schnyder, H. (2009). Analysing the isotopic life history of the alpine ungulates Capra ibex and Rupicapra rupicapra rupicapra through their horns. Rapid Communications in Mass Spectrometry, 23(15), 2347-2356.

Bechshøft, C. L., Schjerling, P., Bornø, A., \& Holm, L. (2017). Existence of life-time stable proteins in mature rats-Dating of proteins' age by repeated short-term exposure to labeled amino acids throughout age. PLoS One, 12(9), e0185605.

Bord Bia, B. (2017). USDA process verified program. Information for farmer suppliers. Revised 01. Retrieved from https://farm.bordbia.ie/pics/Bord\%20Bia $\%$ 20USDA $\% 20$ Process $\% 20$ Verified $\% 20$ Program $\% 20$ Information $\% 20$ for $\% 20$ Farme 
$\% 20$ Suppliers.docx.

Boner, M., \& Förstel, H. (2004). Stable isotope variation as a tool to trace the authenticity of beef. Analytical and Bioanalytical Chemistry, 378(2), 301-310.

Bong, Y.-S., Shin, W.-J., Lee, A., Kim, Y.-S., Kim, K., \& Lee, K. S. (2010). Tracing the geographical origin of beefs being circulated in Korean markets based on stable isotopes. Rapid Communications in Mass Spectrometry, 24(1), 155-159.

Camin, F., Boner, M., Bontempo, L., Fauhl-Hassek, C., Kelly, S. D., Riedl, J., \& Rossmann, A. (2017). Stable isotope techniques for verifying the declared geographical origin of food in legal cases. Trends in Food Science \& Technology, 61, 176-187.

Camin, F., Bontempo, L., Heinrich, K., Horacek, M., Kelly, S. D., Schlicht, C., ... Rossmann, A. (2007). Multi-element (H, C, N, S) stable isotope characteristics of lamb meat from different European regions. Analytical and Bioanalytical Chemistry, 389(1), 309-320.

Capo, R. C., Stewart, B. W., \& Chadwick, O. A. (1998). Strontium isotopes as tracers of ecosystem processes: Theory and methods. Geoderma, 82(1-3), 197-225.

Cassar-Malek, I., Jurie, C., Bernard, C., Barnola, I., Micol, D., \& Hocquette, J.-F. (2009) Pasture-feeding of Charolais steers influences skeletal muscle metabolism and gene expression. Journal of Physiology and Pharmacology, 60(Suppl. 2), 83-90.

Cerling, T. E., Barnette, J. E., Bowen, G. J., Chesson, L. A., Ehleringer, J. R., Remien, C. H., ... West, J. B. (2016). Forensic stable isotope biogeochemistry. Annual Review of Earth and Planetary Sciences, 44, 175-206.

Chesson, L. A., Podlesak, D. W., Thompson, A. H., Cerling, T. E., \& Ehleringer, J. R. (2008). Variation of hydrogen, carbon, nitrogen, and oxygen stable isotope ratios in an American diet: Fast food meals. Journal of Agricultural and Food Chemistry, 56(11), 4084-4091.

Coletta, L. D., Pereira, A. L., Coelho, A. A. D., Savino, V. J. M., Menten, J. F. M., Correr, E., ... Martinelli, L. A. (2012). Barn vs. free-range chickens: Differences in their diets determined by stable isotopes. Food Chemistry, 131(1), 155-160.

Cozzolino, D., De Mattos, D., \& Martins, D. V. (2002). Visible/near infrared reflectance spectroscopy for predicting composition and tracing system of production of beef muscle. Animal Science, 74(3), 477-484.

Daley, C. A., Abbott, A., Doyle, P. S., Nader, G. A., \& Larson, S. (2010). A review of fatty acid profiles and antioxidant content in grass-fed and grain-fed beef. Nutrition Journal, 9(1), 10.

Danezis, G. P., Pappas, A. C., Zoidis, E., Papadomichelakis, G., Hadjigeorgiou, I., Zhang, P., ... Georgiou, C. A. (2017). Game meat authentication through rare earth elements fingerprinting. Analytica Chimica Acta, 991, 46-57.

Danezis, G. P., Tsagkaris, A. S., Camin, F., Brusic, V., \& Georgiou, C. A. (2016), Food authentication: Techniques, trends \& emerging approaches. TrAC Trends in Analytical Chemistry, 85, 123-132.

De Smet, S., Balcaen, A., Claeys, E., Boeckx, P., \& Van, C. O. (2004). Stable carbon isotope analysis of different tissues of beef animals in relation to their diet. Rapid Communications in Mass Spectrometry, 18(11), 1227-1232.

DeNiro, M. J., \& Epstein, S. (1978). Influence of diet on the distribution of carbon isotopes in animals. Geochimica et Cosmochimica Acta, 42(5), 495-506.

Dennis, M. J. (1998). Recent developments in food authentication. Analyst, 123(9), 151R-156R.

Dian, P. H. M., Andueza, D., Jestin, M., Prado, I. N., \& Prache, S. (2008). Comparison of visible and near infrared reflectance spectroscopy to discriminate between pasturefed and concentrate-fed lamb carcasses. Meat Science, 80(4), 1157-1164.

Dian, P. H. M., Chauveau-Duriot, B., Prado, I. N., \& Prache, S. (2007). A dose-response study relating the concentration of carotenoid pigments in blood and reflectance spectrum characteristics of fat to carotenoid intake level in sheep. Journal of Animal Science, 85(11), 3054-3061.

Dias, L., Correia, D. M., Sá-Morais, J., Sousa, F., Pires, J., \& Peres, A. M. (2008). Raw bovine meat fatty acids profile as an origin discriminator. Food Chemistry, 109(4), 840-847.

Donarski, J., \& Heinrich, K. (2016). British Beef origin Project II - Improvement of the British Beef Isotope Landscape Map (Isoscape) for Scotland and Northern Ireland. Retrieved from http://www.foodstandards.gov.scot/publications-and-research/beef origin-project-ii-improvement-of-the-british-beef-isotope-landscape-ma.

Downey, G. (2016). Advances in food authenticity testing. Improving quality throughout the food chain. Cambridge, UK: Woodhead Publishing Ltd.

Duckett, S. K., Pratt, S. L., \& Pavan, E. (2009). Corn oil or corn grain supplementation to steers grazing endophyte-free tall fescue. II. Effects on subcutaneous fatty acid content and lipogenic gene expression. Journal of Animal Science, 87(3), 1120-1128.

Dunne, P. G., Monahan, F. J., O'Mara, F. P., \& Moloney, A. P. (2009). Colour of bovine subcutaneous adipose tissue: A review of contributory factors, associations with carcass and meat quality and its potential utility in authentication of dietary history. Meat Science, 81(1), 28-45.

EC (2018). European commision agriculture and food - database of origin \& registration (DOOR). Retrieved from https://ec.europa.eu/agriculture/quality/schemes/ foodstuff en.

Erasmus, S. W., Manley, M., Muller, M., \& Hoffman, L. C. (2016). MicroNIR spectroscopy for the authentication of south African lamb. Proceedings of 62nd international congress of meat science and technology: Meat for global sustainability, (Bangkok, Thailand, 14-19 August) (pp. 36). .

Erasmus, S. W., Muller, M., Butler, M., \& Hoffman, L. C. (2018). The truth is in the isotopes: Authenticating regionally unique south African lamb. Food Chemistry, 239, 926-934.

Franke, B. M., Hadorn, R., Bosset, J. O., Gremaud, G., \& Kreuzer, M. (2008). Is authentication of the geographic origin of poultry meat and dried beef improved by combining multiple trace element and oxygen isotope analysis? Meat Science, 80(3), 944-947.

Franke, B. M., Haldimann, M., Gremaud, G., Bosset, J.-O., Hadorn, R., \& Kreuzer, M. (2008). Element signature analysis: Its validation as a tool for geographic authentication of the origin of dried beef and poultry meat. European Food Research and
Technology, 227(3), 701-708.

Franke, B. M., Haldimann, M., Reimann, J., Baumer, B., Gremaud, G., Hadorn, R., ... Kreuzer, M. (2007). Indications for the applicability of element signature analysis for the determination of the geographic origin of dried beef and poultry meat. European Food Research and Technology, 225(3-4), 501-509.

Franke, B. M., Koslitz, S., Micaux, F., Piantini, U., Maury, V., Pfammatter, E., ... Hadorn, R. (2008). Tracing the geographic origin of poultry meat and dried beef with oxygen and strontium isotope ratios. European Food Research and Technology, 226(4), 761-769.

FSA (2013). Report of the investigation by the Food Standards Agency into incidents of adulteration of comminuted beef products with horse meat and DNA. Retrieved from https://www.reading.ac.uk/foodlaw/pdf/uk-13014-horse-meat-summary.pdf.

Gamboa-Delgado, J., Molina-Poveda, C., Godínez-Siordia, D. E., Villarreal-Cavazos, D, Ricque-Marie, D., \& Cruz-Suárez, L. E. (2014). Application of stable isotope analysis to differentiate shrimp extracted by industrial fishing or produced through aquaculture practices. Canadian Journal of Fisheries and Aquatic Sciences, 71(10), 1520-1528.

Gebbing, T., Schellberg, J., \& Kühbauch, W. (2004). Switching from grass to maize diet changes the $\mathrm{C}$ isotope signature of meat and fat during fattening of steers. Land use systems in grassland dominated regions. Proceedings of the 20th general meeting of the European grassland federation, Luzern, Switzerland, 21-24 June 2004 (pp. 11301132).

González-Martin, I., González-Pérez, C., Mendez, J. H., Marqués-Macias, E., \& Poveda, F. S. (1999). Use of isotope analysis to characterize meat from Iberian-breed swine. Meat Science, 52(4), 437-441.

Guo, B. L., Wei, Y. M., Pan, J. R., \& Li, Y. (2010). Stable C and N isotope ratio analysis for regional geographical traceability of cattle in China. Food Chemistry, 118(4), 915-920.

Harrison, S. M., Schmidt, O., Moloney, A. P., Kelly, S. D., Rossmann, A., Schellenberg, A. ... Monahan, F. J. (2011). Tissue turnover in ovine muscles and lipids as recorded by multiple (H, C, O, S) stable isotope ratios. Food Chemistry, 124(1), 291-297.

Harrison, S. M., Zazzo, A., Bahar, B., Monahan, F. J., Moloney, A. P., Scrimgeour, C. M., \& Schmidt, O. (2007). Using hooves for high-resolution isotopic reconstruction of bovine dietary history. Rapid Communications in Mass Spectrometry, 21(4), 479-486.

Heaton, K., Kelly, S. D., Hoogewerff, J., \& Woolfe, M. (2008). Verifying the geographical origin of beef: The application of multi-element isotope and trace element analysis. Food Chemistry, 107(1), 506-515.

Henchion, M., McCarthy, M., Resconi, V. C., \& Troy, D. (2014). Meat consumption: Trends and quality matters. Meat Science, 98(3), 561-568.

Hobson, K. A. (1999). Tracing origins and migration of wildlife using stable isotopes: A review. Oecologia, 120(3), 314-326.

Hocquette, J.-F., Cassar-Malek, I., Bernard-Capel, C., \& Picard, B. (2009). Functional genomics and new markers for beef production-minireview. Animal Science Papers and Reports, 27, 273-279.

Huang, Y., Andueza, D., de Oliveira, L., Zawadzki, F., \& Prache, S. (2015). Comparison of visible and near infrared reflectance spectroscopy on fat to authenticate dietary history of lambs. Animal, 9(11), 1912-1920.

Identigen (2018). Retrieved from https://identigen.com/dna-traceback/.

Jahren, A. H., \& Kraft, R. A. (2008). Carbon and nitrogen stable isotopes in fast food: Signatures of corn and confinement. Proceedings of the National Academy of Sciences 105(46), 17855-17860.

Kelly, S., Heaton, K., \& Hoogewerff, J. (2005). Tracing the geographical origin of food: The application of multi-element and multi-isotope analysis. Trends in Food Science \& Technology, 16(12), 555-567.

Kim, J. S., Hwang, I. M., Lee, G. H., Park, Y. M., Choi, J. Y., Jamila, N., ... Kim, K. S. (2017). Geographical origin authentication of pork using multi-element and multivariate data analyses. Meat Science, 123, 13-20.

Krouse, H. R., \& Grinenko, V. A. (1991). Stable isotopes: Natural and anthropogenic Sulphur in the environment (SCOPE 43). Chichester. New York, Brisbane, Toronto, Singapore: Wiley.

Lees, M. (2003). Food authenticity and traceability. Cambridge, UK: Woodhead Publishing Limited.

Li, L., Boyd, C. E., \& Sun, Z. (2016). Authentication of fishery and aquaculture products by multi-element and stable isotope analysis. Food Chemistry, 194, 1238-1244.

Liu, X., Guo, B., Wei, Y., Shi, J., \& Sun, S. (2013). Stable isotope analysis of cattle tail hair: A potential tool for verifying the geographical origin of beef. Food Chemistry, 140(1-2), 135-140.

Lohumi, S., Lee, S., Lee, H., \& Cho, B.-K. (2015). A review of vibrational spectroscopic techniques for the detection of food authenticity and adulteration. Trends in Food Science \& Technology, 46(1), 85-98.

Luciano, G., Moloney, A. P., Priolo, A., Röhrle, F. T., Vasta, V., Biondi, L., ... Monahan, F. J. (2011). Vitamin E and polyunsaturated fatty acids in bovine muscle and the oxidative stability of beef from cattle receiving grass or concentrate-based rations. Journal of Animal Science, 89(11), 3759-3768.

Luykx, D. M. A. M., \& Van Ruth, S. M. (2008). An overview of analytical methods for determining the geographical origin of food products. Food Chemistry, 107(2), 897-911.

Mariaca, R. G., Berger, T. F. H., Gauch, R., Imhof, M. I., Jeangros, B., \& Bosset, J. O. (1997). Occurrence of volatile mono-and sesquiterpenoids in highland and lowland plant species as possible precursors for flavor compounds in milk and dairy products. Journal of Agricultural and Food Chemistry, 45(11), 4423-4434.

Martinelli, L. A., Nardoto, G. B., Chesson, L. A., Rinaldi, F. D., Ometto, J. P. H. B., Cerling, T. E., \& Ehleringer, J. R. (2011). Worldwide stable carbon and nitrogen isotopes of Big Mac ${ }^{\oplus}$ patties: An example of a truly "glocal" food. Food Chemistry, 127(4), 1712-1718.

McCluskey, J. J., Wahl, T. I., Li, Q., \& Wandschneider, P. R. (2005). US grass-fed beef: 
Marketing health benefits. Journal of Food Distribution Research, 36(3), 1.

Meglia, G. E., Jensen, S. K., Lauridsen, C., \& Waller, K. P. (2006), $\alpha$-tocopherol concentration and stereoisomer composition in plasma and milk from dairy cows fed natural or synthetic vitamin E around calving. Journal of Dairy Research, 73(2), 227-234.

Moloney, A. P., O'Riordan, E., Schmidt, O., \& Monahan, F. J. (2018). The fatty acid profile and stable isotope ratios of $\mathrm{C}$ and $\mathrm{N}$ of muscle from cattle that grazed grass or grass/ clover pastures before slaughter and their discriminatory potential. Irish Journal of Agricultural and Food Research (in press).

Monahan, F. J., Buckley, D. J., Morrissey, P. A., Lynch, P. B., \& Gray, J. I. (1990). Effect of dietary $\alpha$-tocopherol supplementation on $\alpha$-tocopherol levels in porcine tissues and on susceptibility to lipid peroxidation. Food Science and Nutrition, 42(4), 203-212.

Monahan, F. J., Schmidt, O., Moloney, A. P., Dunne, P. G., Scrimgeour, C. M., Begley, I. S., ... Pearce, R. (2006). Temporal change in the carbon stable isotope ratios of beef following a change in ration composition. Paper presented at the proceedings of the 52nd international congress of meat science and Technology (pp. 667-668).

Monteiro, A., Fontes, M., Bessa, R., Prates, J., \& Lemos, J. (2012). Intramuscular lipids of Mertolenga-PDO beef, Mertolenga-PDO veal and "Vitela Tradicional do Montado"PGI veal. Food Chemistry, 132(3), 1486-1494.

Montgomery, J., Evans, J. A., \& Wildman, G. (2006). 87Sr/86Sr isotope composition of bottled British mineral waters for environmental and forensic purposes. Applied Geochemistry, 21(10), 1626-1634.

Montowska, M., \& Pospiech, E. (2012). Is authentication of regional and traditional food made of meat possible? Critical Reviews in Food Science and Nutrition, 52(6), 475-487.

Moreno-Rojas, J. M., Vasta, V., Lanza, A., Luciano, G., Ladroue, V., Guillou, C., \& Priolo, A. (2008). Stable isotopes to discriminate lambs fed herbage or concentrate both obtained from C3 plants. Rapid Communications in Mass Spectrometry, 22(23), 3701-3705.

Nader, W. F., Brendel, T., \& Schubbert, R. (2016). Advances in DNA fingerprinting for food authenticity testing. In G. Downey (Ed.). Advances in food authenticity testing (pp. 7-33). Elsevier, Woodhead Publishing.

Nakashita, R., Suzuki, Y., Akamatsu, F., Iizumi, Y., Korenaga, T., \& Chikaraishi, Y. (2008). Stable carbon, nitrogen, and oxygen isotope analysis as a potential tool for verifying geographical origin of beef. Analytica Chimica Acta, 617(1-2), 148-152.

Noci, F., Monahan, F. J., French, P., \& Moloney, A. P. (2005). The fatty acid composition of muscle fat and subcutaneous adipose tissue of pasture-fed beef heifers: Influence of the duration of grazing. Journal of Animal Science, 83(5), 1167-1178.

Oliveira, G. B., Alewijn, M., Boerrigter-Eenling, R., \& van Ruth, S. M. (2015). Compositional signatures of conventional, free range, and organic pork meat using fingerprint techniques. Food, 4(3), 359-375.

Osorio, M. T., Moloney, A. P., Brennan, L., \& Monahan, F. J. (2012), Authentication of beef production systems using a metabolomic-based approach. Animal, 6(1), 167-172.

Osorio, M. T., Moloney, A. P., Schmidt, O., \& Monahan, F. J. (2011a). Beef authentication and retrospective dietary verification using stable isotope ratio analysis of bovine muscle and tail hair. Journal of Agricultural and Food Chemistry, 59(7), 3295-3305.

Osorio, M. T., Moloney, A. P., Schmidt, O., \& Monahan, F. J. (2011b). Multielement isotope analysis of bovine muscle for determination of international geographical origin of meat. Journal of Agricultural and Food Chemistry, 59(7), 3285-3294.

Perini, M., Camin, F., Bontempo, L., Rossmann, A., \& Piasentier, E. (2009). Multielement $(\mathrm{H}, \mathrm{C}, \mathrm{N}, \mathrm{O}, \mathrm{S})$ stable isotope characteristics of lamb meat from different Italian regions. Rapid Communications in Mass Spectrometry, 23(16), 2573-2585.

Piasentier, E., Valusso, R., Camin, F., \& Versini, G. (2003). Stable isotope ratio analysis for authentication of lamb meat. Meat Science, 64(3), 239-247.

Prache, S. (2009). Diet authentication in sheep from the composition of animal tissues and products. Revista Brasileira de Zootecnia, 38(SPE), 362-370.

Prache, S., Priolo, A., \& Grolier, P. (2003a). Effect of concentrate finishing on the carotenoid content of perirenal fat in grazing sheep: Its significance for discriminating grass-fed, concentrate-fed and concentrate-finished grazing lambs. Animal Science, $77(2), 225-233$

Prache, S., Priolo, A., \& Grolier, P. (2003b). Persistence of carotenoid pigments in the blood of concentrate-finished grazing sheep: Its significance for the traceability of grass-feeding. Journal of Animal Science, 81(2), 360-367.

Prache, S., \& Theriez, M. (1999). Traceability of lamb production systems: Carotenoids in plasma and adipose tissue. Animal Science, 69(1), 29-36.

Prieto, N., Juarez, M., Larsen, I., Lopez-Campos, O., Zijlstra, R., \& Aalhus, J. (2015). Rapid discrimination of enhanced quality pork by visible and near infrared spectroscopy. Meat Science, 110, 76-84.

Primrose, S., Woolfe, M., \& Rollinson, S. (2010). Food forensics: Methods for determining the authenticity of foodstuffs. Trends in Food Science \& Technology, 21(12), 582-590.

Priolo, A., Cornu, A., Prache, S., Krogmann, M., Kondjoyan, N., Micol, D., \& Berdagué, J.L. (2004). Fat volatiles tracers of grass feeding in sheep. Meat Science, 66(2), 475-481.

Priolo, A., Prache, S., Micol, D., \& Agabriel, J. (2002). Reflectance spectrum of adipose tissue to trace grass feeding in sheep: Influence of measurement site and shrinkage time after slaughter. Journal of Animal Science, 80(4), 886-891.

Rees, G., Kelly, S. D., Cairns, P., Ueckermann, H., Hoelzl, S., Rossmann, A., \& Scotter, M. J. (2016). Verifying the geographical origin of poultry: The application of stable isotope and trace element (SITE) analysis. Food Control, 67, 144-154.

Renou, J.-P., Bielicki, G., Deponge, C., Gachon, P., Micol, D., \& Ritz, P. (2004). Characterization of animal products according to geographic origin and feeding diet using nuclear magnetic resonance and isotope ratio mass spectrometry. Part II: Beef meat. Food Chemistry, 86(2), 251-256.

Rhodes, C. N., Lofthouse, J. H., Hird, S., Rose, P., Reece, P., Christy, J., ... Brereton, P. A. (2010). The use of stable carbon isotopes to authenticate claims that poultry have been corn-fed. Food Chemistry, 118(4), 927-932.
Richter, E. K., Spangenberg, J. E., Willems, H., Kreuzer, M., \& Leiber, F. (2012). Stable carbon isotope composition of perirenal adipose tissue fatty acids from Engadine sheep grazing either mountain or lowland pasture. Journal of Animal Science, 90(3), 905-913.

Ripoll, G., Lobón, S., \& Joy, M. (2018). Use of visible and near infrared reflectance spectra to predict lipid peroxidation of light lamb meat and discriminate dam's feeding systems. Meat Science, 143, 24-29.

Röhrle, F. T., Moloney, A. P., Black, A., Osorio, M. T., Sweeney, T., Schmidt, O., \& Monahan, F. J. (2011). $\alpha$-tocopherol stereoisomers in beef as an indicator of vitamin E supplementation in cattle diets. Food Chemistry, 124(3), 935-940.

Röhrle, F. T., Moloney, A. P., Osorio, M. T., Luciano, G., Priolo, A., Caplan, P., \& Monahan, F. J. (2011). Carotenoid, colour and reflectance measurements in bovine adipose tissue to discriminate between beef from different feeding systems. Meat Science, 88(3), 347-353.

Rossmann, A., Haberhauer, G., Hölzl, S., Horn, P., Pichlmayer, F., \& Voerkelius, S. (2000) The potential of multielement stable isotope analysis for regional origin assignment of butter. European Food Research and Technology, 211(1), 32-40.

Rossmann, A., \& Schlicht, C. (2007). Stable isotope analysis for origin assignment of animal products. Fleischwirtschaft, 87(8), 104-109.

Rozanski, K., Araguas-Araguas, L., \& Gonfiantini, R. (1992). Relation between long-term trends of oxygen-18 isotope composition of precipitation and climate. Science, 258(5084), 981-985.

Rummel, S., Dekant, C. H., Hölzl, S., Kelly, S. D., Baxter, M., Marigheto, N., ... Fröschl, H. (2012). Sr isotope measurements in beef-Analytical challenge and first results. Analytical and Bioanalytical Chemistry, 402(9), 2837-2848.

Rummel, S., Hoelzl, S., Horn, P., Rossmann, A., \& Schlicht, C. (2010). The combination of stable isotope abundance ratios of $\mathrm{H}, \mathrm{C}, \mathrm{N}$ and $\mathrm{S}$ with $87 \mathrm{Sr} / 86 \mathrm{Sr}$ for geographical origin assignment of orange juices. Food Chemistry, 118(4), 890-900.

Schmidt, O., Quilter, J. M., Bahar, B., Moloney, A. P., Scrimgeour, C. M., Begley, I. S., \& Monahan, F. J. (2005). Inferring the origin and dietary history of beef from C, N and S stable isotope ratio analysis. Food Chemistry, 91(3), 545-549.

Schnyder, H., Schwertl, M., Auerswald, K., \& Schaeufele, R. (2006). Hair of grazing cattle provides an integrated measure of the effects of site conditions and interannual weather variability on $\delta^{13} \mathrm{C}$ of temperate humid grassland. Global Change Biology, 12(7), 1315-1329.

Schwertl, M., Auerswald, K., Schäufele, R., \& Schnyder, H. (2005). Carbon and nitrogen stable isotope composition of cattle hair: Ecological fingerprints of production systems? Agriculture, Ecosystems \& Environment, 109(1-2), 153-165.

Schwertl, M., Auerswald, K., \& Schnyder, H. (2003). Reconstruction of the isotopic history of animal diets by hair segmental analysis. Rapid Communications in Mass Spectrometry, 17(12), 1312-1318.

Scollan, N. D., Dannenberger, D., Nuernberg, K., Richardson, I., MacKintosh, S. Hocquette, J.-F., \& Moloney, A. P. (2014). Enhancing the nutritional and health value of beef lipids and their relationship with meat quality. Meat Science, 97(3), 384-394.

Sentandreu, M.Á., \& Sentandreu, E. (2014). Authenticity of meat products: Tools against fraud. Food Research International, 60, 19-29.

Serrano, E., Cornu, A., Kondjoyan, N., Agabriel, J., \& Micol, D. (2011). Traceability of grass feeding in beef: Terpenes, 2, 3-octanedione and skatole accumulation in adipose tissue of young bulls. Animal, 5(4), 641-649.

Serrano, E., Cornu, A., Kondjoyan, N., Figueredo, G., Agabriel, J., \& Micol, D. (2007) Terpene accumulation in muscle and fatty tissues of calves supplemented with essential oils. Journal of Animal and Feed Sciences, 16(2), 168.

Shibata, M., Matsumoto, K., Oe, M., Ohnishi-Kameyama, M., Ojima, K., Nakajima, I., .. Chikuni, K. (2009). Differential expression of the skeletal muscle proteome in grazed cattle. Journal of Animal Science, 87(8), 2700-2708.

Shingfield, K. J., Bonnet, M., \& Scollan, N. D. (2013). Recent developments in altering the fatty acid composition of ruminant-derived foods. Animal, 7(s1), 132-162.

Shintu, L., Caldarelli, S., \& Franke, B. M. (2007). Pre-selection of potential molecular markers for the geographic origin of dried beef by HR-MAS NMR spectroscopy. Meat Science, 76(4), 700-707.

Smith, B. N., \& Epstein, S. (1971). Two categories of 13C/12C ratios for higher plants. Plant Physiology, 47(3), 380-384.

Sponheimer, M., Robinson, T. F., Cerling, T. E., Tegland, L., Roeder, B. L., Ayliffe, L., .. Ehleringer, J. R. (2006). Turnover of stable carbon isotopes in the muscle, liver, and breath $\mathrm{CO}_{2}$ of alpacas (Lama pacos). Rapid Communications in Mass Spectrometry, 20(9), 1395-1399.

Sun, D.-W. (2008). Modern techniques for food authentication. Amsterdam: Academic Press. Sun, S., Guo, B., Wei, Y., \& Fan, M. (2012). Classification of geographical origins and prediction of $\delta^{13} \mathrm{C}$ and $\delta^{15} \mathrm{~N}$ values of lamb meat by near infrared reflectance spectroscopy. Food Chemistry, 135(2), 508-514.

Sweeney, T., Lejeune, A., Moloney, A. P., Monahan, F. J., Mc Gettigan, P., Downey, G., ... Ryan, M. T. (2016). The application of transcriptomic data in the authentication of beef derived from contrasting production systems. BMC Genomics, 17(1), 746.

Tornambé, G., Cornu, A.l., Pradel, P., Kondjoyan, N., Carnat, A. P., Petit, M., \& Martin, B. (2006). Changes in terpene content in milk from pasture-fed cows. Journal of Dairy Science, 89(6), 2309-2319.

Vasta, V., Luciano, G., Dimauro, C., Röhrle, F. T., Priolo, A., Monahan, F. J., \& Moloney, A. P. (2011). The volatile profile of longissimus dorsi muscle of heifers fed pasture, pasture silage or cereal concentrate: Implication for dietary discrimination. Meat Science, 87(3), 282-289.

Vasta, V., \& Priolo, A. (2006). Ruminant fat volatiles as affected by diet. A review. Meat Science, 73(2), 218-228.

Vasta, V., Ratel, J., \& Engel, E. (2007). Mass spectrometry analysis of volatile compound in raw meat for the authentication of the feeding background of farm animals. Journal of Agricultural and Food Chemistry, 55(12), 4630-4639.

Vinci, G., Preti, R., Tieri, A., \& Vieri, S. (2013). Authenticity and quality of animal origin 
food investigated by stable-isotope ratio analysis. Journal of the Science of Food and Agriculture, 93(3), 439-448.

West, A. G., Ayliffe, L. K., Cerling, T. E., Robinson, T. F., Karren, B., Dearing, M. D., \& Ehleringer, J. R. (2004). Short-term diet changes revealed using stable carbon isotopes in horse tail-hair. Functional Ecology, 18(4), 616-624.

WHO/FAO (2007). Codex Alimentarius. Food import and export inspection and certification systems (3rd ed.). World Health Organization - Food and Agriculture Organization of the United Nations79.

Woods, V. B., \& Fearon, A. M. (2009). Dietary sources of unsaturated fatty acids for animals and their transfer into meat, milk and eggs: A review. Livestock Science, 126(1), $1-20$.

Zazzo, A., Harrison, S. M., Bahar, B., Moloney, A. P., Monahan, F. J., Scrimgeour, C. M., \& Schmidt, O. (2007). Experimental determination of dietary carbon turnover in bovine hair and hoof. Canadian Journal of Zoology, 85(12), 1239-1248.

Zazzo, A., Moloney, A. P., Monahan, F. J., Scrimgeour, C. M., \& Schmidt, O. (2008). Effect of age and food intake on dietary carbon turnover recorded in sheep wool. Rapid Communications in Mass Spectrometry, 22(18), 2937-2945.

Zazzo, A., Monahan, F. J., Moloney, A. P., Green, S., \& Schmidt, O. (2011). Sulphur isotopes in animal hair track distance to sea. Rapid Communications in Mass Spectrometry, 25(17), 2371-2378.

Zhao, Y., Zhang, B., Chen, G., Chen, A., Yang, S., \& Ye, Z. (2013). Tracing the geographic origin of beef in China on the basis of the combination of stable isotopes and multielement analysis. Journal of Agricultural and Food Chemistry, 61(29), 7055-7060.

Zhao, Y., Zhang, B., Guo, B., Wang, D., \& Yang, S. (2016). Combination of multi-element and stable isotope analysis improved the traceability of chicken from four provinces of China. CyTA-Journal of Food, 14(2), 163-168. 